\title{
Genforeningen i dansk digtning
}

\author{
af $H$. E. Sørensen
}

Næppe nogen begivenhed i dette århundrede har gjort så dybt indtryk på danskerne som Genforeningen i 1920. I hundredvis af digte tolkede store og små poeter de følelser, som trængte sig på i tiden omkring afstemningen, grænsedragningen og genforeningsfesterne. Forfatteren og museumsmanden H. E. Sørensen, Skærbæk, har set på en række af de mange hundrede digte. De fortæller bedre end mange kilder om befolkningens tanker og følelser dengang.

Store og afgørende begivenheder $\mathrm{i}$ et folks historie vil altid give sig udtryk $\mathrm{i}$ litteraturen, da digtningen er et spejl af, hvad der rører sig i menneskene. Det gælder i nyere tid f.eks. nederlaget i 1864, besættelsen i 1940, befrielsen 1945 og tilslutningen til EF 1972, hvor ikke mindst modstanden aktiverede digterne.

Og det gælder i ganske særlig grad afstemningstiden og Genforeningen 1920, »den glædeligste begivenhed i vor tid«, som den er blevet kaldt, hvor Danmark for første gang i århundreder blev større. Efter utallige generationer, hvor Danmarkshistorien består af en næsten ubrudt række af nederlag, så snart vi kom i konflikt med vore naboer, oplevedes Genforeningen som en sejr, en rettens sejr, oven i købet vundet, uden at Danmark direkte havde været indblandet $i$ krigshandlinger. Nok var Genforeningen i sidste ende et resultat af den store krig 1914-18 og Tysklands nederlag, men sønderjyderne - og dermed Danmark - vandt også gennem sejt slid, trofasthed og passiv modstand, og i sidste ende ved brug af stemmesedlen, og det så overbevisende, at ingen med rette har kunnet anfægte den grænse, som blev draget for 75 år siden. Den er en af de få grænser, måske den eneste, i Europa, der er bestemt af de mennesker, den direkte angik, dem, der boede på begge sider af den. Man kan måske kalde den Europas mest demokratiske grænse.

Begivenheder, der udløser så stærke følelser som Genforeningen, giver sig også udtryk i brug af store ord, som en eftertid måske har svært ved helt at tage for pålydende. Men der er nok ingen tvivl om, at de i situationen var dækkende for, hvad mange - vel flertallet - følte. Hvis senere generationer skal forsøge at sætte sig ind i, hvorledes de mennesker, der stod midt $i$ begivenhederne, oplevede dem, er den nøgterne historieskrivning ikke altid tilstrækkelig. Så er tal, referater og vurderinger, hvor oplysende de end kan være, ikke dækkende. De giver mere eftertidens billede end samtidens.

Vil man stille sig i de menneskers sted, som oplevede begivenhederne, og 
forsøge at sætte sig ind i, hvordan de oplevede dem, er man nødt til at gå til digterne så vel som andre kunstnere. Det er dem, der mere end nogen andre er deres samtids talsmænd.

Op til afstemningerne og Genforeningen $1920 \mathrm{og}$ i tiden umiddelbart efter fremkom der et meget stort antal digte, nogle skrevet af landets kendteste digtere, andre af mere ukendte og lokale rimsmede. I forbindelse med udarbejdelsen af denne artikel har jeg gennemgået ca. 300 digte, og der er givetvis mange flere, nok især lokalt forfattede sange, som har været anvendt ved festligheder i forsamlingshuse o.l. Antallet kan meget vel løbe op imod 500 digte og sange. De mere lokale frembringelser falder dog uden for denne artikels rammer, men påtænkes behandlet ved en senere lejlighed. Derfor håber jeg, at folk med kendskab til sådanne digte og sange - evt. trykt i små hæfter, afskrevne, duplikerede eller offentliggjort på anden måde - vil sende dem (helst i original, men ellers i fotokopi) til undertegnede, så de kan blive registreret og opbevaret for eftertiden.

\section{Digtenes symbolverden}

Ved gennemgangen af de mange digte viste det sig, at en række symboler går igen $i$ de fleste digte. Ofte kan der være tale om rene ophobninger af disse symboler, der sammen med lån fra kendte fædrelandssange og salmer danner et fast sæt af klichéer.

Der er tale om både positive og negative symboler, alt efter om man taler om dansk eller tysk, og den positive, d.v.s. den danske række, er den længste og mest nuancerede.

De enkelte symboler anvendes så ofte, at der næppe er et digt, der ikke har en række af dem repræsenteret. Da det i sagens natur kun er muligt at bringe korte uddrag fra digtene, vil det ikke klart fremgå af citatmaterialet, hvor ofte og i hvilket omfang de enkelte symboler er brugt.

De positive/danske symboler kan inddeles i fire hovedkategorier: hjemmet, naturen, historien og religionen.

\section{Hjemmets symboler:}

Den rovede datter, der vender hjem fra »bolt og fangejern«.

Moderen, Mor Danmark, der modtager datteren.

De sønderjyske piger, der fremstilles kyske, rene og jomfruelige, ofte i modsætning til tysk brutalitet og brunst.

De elskende, Sønderjylland og Danmark, der endelig forenes. 


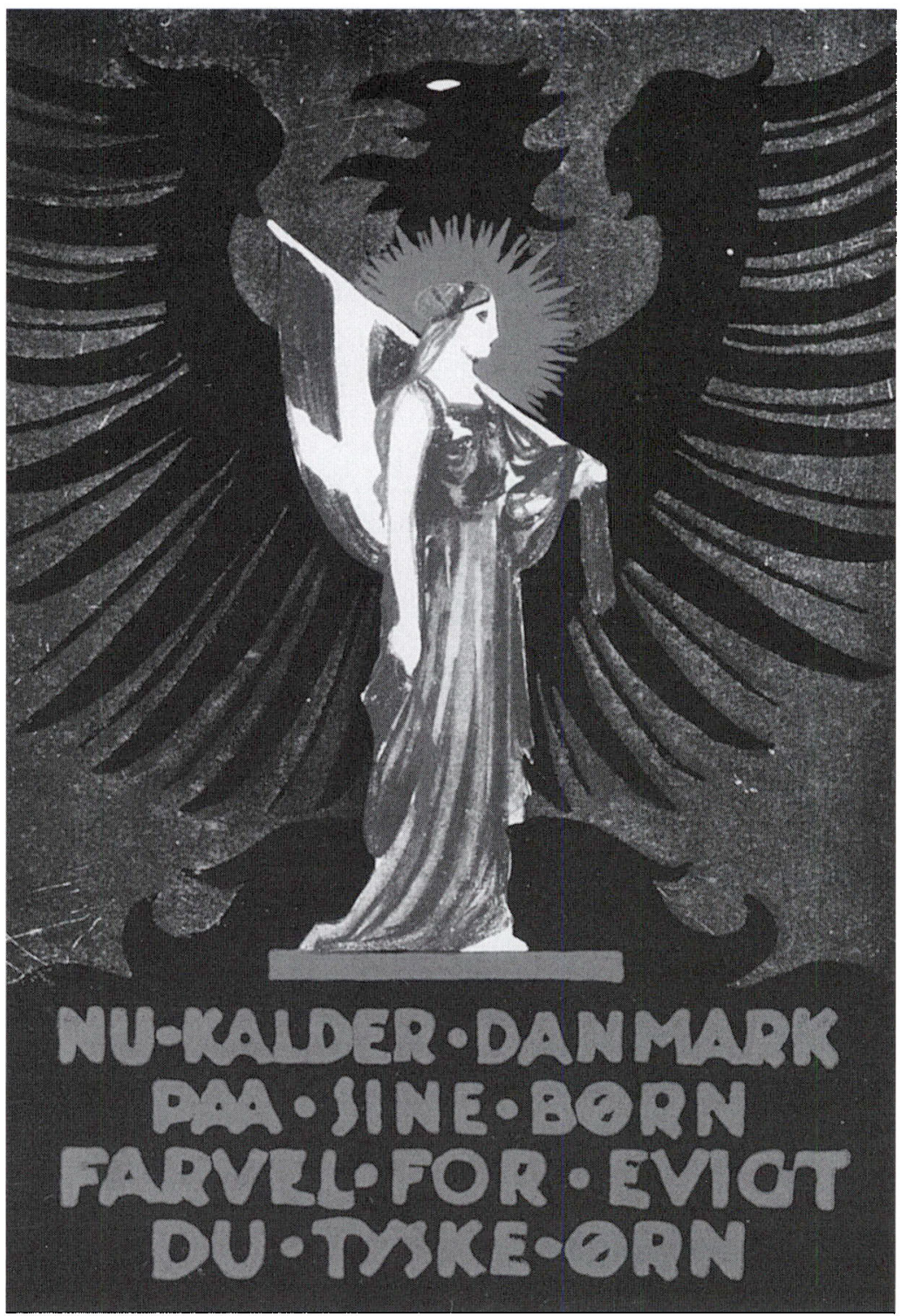

Plakaterne fra afstemningstiden afspejler de samme folelser og bruger de samme symboler som digtene. $P a ̊$ denne plakat, tegnet af kunstneren Thor Bogelund, er Danmark fremstillet som en lys, nasten akvarelagtigt malet kvindeskikkelse med Dannebrog, sat effektfuldt op på baggrund af den truende sorte tyske orn med ildøje. Det fyndige rim (Nu kalder Danmark på sine born. / farvel for evigt, du tyske orn), der har slagordets enkle styrke, og som derfor er let at huske, er forfattet af sonderjyden Hans Ahlmann, der var ansat ved H. P. Hanssens sonderjyske ministerium 1919. 
Hjemmets tryghed, det nære, det kendte, det varme.

Sproget, ofte Danmarks milde sprog (i modsætning til det »hårde« tyske).

Naturens symboler:

Morgenen, dagen, der bryder frem; gryet; solen, som stiger.

Foråret, hvor alt spirer og gror.

Sommeren, lys, varme, lykke.

Larken, lærkesang, ofte Dybbøllærken, som iflg. overleveringen sang over skanserne og ved Genforeningsfesten 1920.

Det milde danske vejr (i modsætning til det åbenbart mere barske tyske vejr).

Historiens symboler:

Det gamle flag, som evt. har været gemt på kistebunden siden 1864, men som nu atter tages frem og hejses, da det igen kan »vaje frit «.

Dannebrog, »der faldt fra himlen ned « i slaget ved Lyndanisse 1219.

De faldne i fortidens krige, både i de slesvigske krige 1848-50 og 1864 og i verdenskrigen. De »betalte med deres blod« for Sønderjyllands »frigivelse« og tilbagevenden (offer-symbolik).

Historien som helhed, ofte den ældre historie, vikingetiden og de gamle asaguder, kampene mod venderne, i det hele Danmarks glorværdige fortid, danskernes tapperhed og tålmodighed.

Dannevirke, ofte omskrevet som Thyras vold, Danmarks vold, den gamle grænsevold eller diget mod sønder. Ledet, der skal sættes i lave.

Thyra Danebod, som byggede Dannevirke.

Dybbøl og Skamlingsbanken med møllen og støtten, der ødelagdes af tyskerne 1864 , og som begge genrejstes af danskerne som nationale symboler.

Kongeåen, den »sorgomsuste«, der adskilte, men nu forener.

Norden, samhørigheden med især Norge og Sverige.

Kongen på den hvide hest, der red ind i det genvundne land.

Greven, der sagde »du« til kongen på Dybbøl som eksempel på dansk jævnhed i modsætning til de »stive« og »højtidelige« prøjsere.

I sagens natur optræder disse to sidste symboler kun i digte, der er skrevet efter kongens ridt over grænsen og Dybbølfesten 1920.

De religiose symboler:

Retfxardigheden, lønnen for folkets tålmodige kamp, venten og liden. Lid og tål, og den deraf følgende belønning. Herren gav - Herren tog, i omvendt rækkefølge!

Offeret, de faldne soldater døde ikke forgæves. Med deres blod betalte de folkets frihed, næsten som en Kristusskikkelse. 
Fadrenes bonner, herunder de faldne soldater, som bad for deres folk.

Han, som har hjulpet hidindtil, han hjæelper nok herefter.

Gud, som bl.a. gav os Dannebrog.

De negative symboler:

som repræsenterer det onde, d.v.s. i denne forbindelse det tyske, er knap så varierede i udbud:

Den tyske orn, ofte med knækket vinge.

De sorte gransepale, der skilte sønderjyderne fra Danmark.

Tysk grumhed, modsat dansk mildhed.

Pikkelhuen som symbol på tysk militarisme.

Projservalde og Köllertid, undertrykkelse af danskheden.

Pansernave, militarisme og verdenskrig.

Junkerstøvler, bryskhed og officersmanerer.

Knivsbjergs »truende« tårn og Bismarckstatue som symbol på tysk tilstedeværelse og magtbud.

Ud over de næunte klichéer gør - især i de mere »amatøragtige« digte - en vis sproglig fattigdom sig gældende i form af mere eller mindre dækte citater, ofte rene lån fra kendte salmer og ældre fædrelandssange. Ikke mindst »Dannevirkevisen «, skrevet af Laurids Kock o. 1685, og den norske nationalsang (»Ja, vi elsker dette landet $($ ), forfattet af Bjørnstjerne Bjørnson 1859, måtte holde for. Men i øvrigt er der hyppige allusioner til digtere som Grundtvig, Oehlenschlæger og Ingemann.

\section{Pontoppidan og Rørdam}

Det digt, der er kommet til at stå som den klassiske genforeningssang, var et af de første digte, der blev skrevet, efter at løftet om en folkeafstemning i de nordlige egne af Slesvig var afgivet i oktober 1918. Det er Henrik Pontoppidans »Sønderjylland «, der oprindelig blev trykt i »Berlingske Tidende« søndagstillæg »Ude og Hjemme« juledag 1918 og gengivet i »Flensborg Avis« få dage senere (31/12). Avisen havde opfordret en række forfattere til at deltage $i$ en enquete om Sønderjylland, og som landets mest berømte og feterede skribent, der havde modtaget Nobelprisen året før, var Pontoppidan selvskreven til at blive indbudt. Oprindelig havde han sagt nej til at være med, men sendte alligevel det lille digt ind, som var opstået under hans morgenspadseretur nogle dage forinden, da et smukt solskin havde sat ham i den rette stemning, og hvis første vers lyder: 


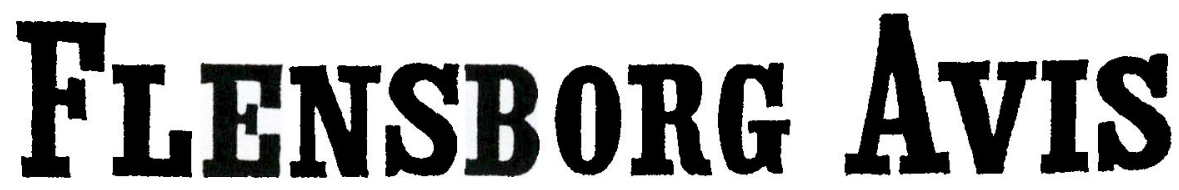

\section{Sonderiylland.}

-Berilingske Tidende* bringor $i$ of righoldigt osnderjysk Julenummer folgondo konne og varmtfolto Digt af Honrik Pontoppldan:

Det lyder som et Eventyr, et Sagn fra gamle Dage: en røvet Datter, dybt begrædt, er kommen frelst tilbagel

Det sker, hvad som et Drømmesyn har straalet for vor Tanke! Til Sommer, vajer Danebrog igen paa Dybbal Bankel

Hrad knap vi tarde hviske om i Krogen mellem Venner, forkyndes nu paa Dansk og Tysk som Lofteord af Frænder.

Velkommen hjem til Moders Has, vor Sester, hjertenskære! Saa bleg du blev i Kæmpens Favn i Striden for din Erel

Du sad i Bolt on Fangejern til Spot for vilde Drenge. Seks Tusind ange Sønners Liv var dine Losepengel

Men du vil ingen Sørgefest! Mens Taaren Øjet brænder, da skjuler stolt, hvad ondt du led $\mathrm{i}$ hino Boddelhænder.

Du kommer klædt i hvidt og rodt on smiler os i Møde. Hil dig, vor Moders Øjensten, i Nytids-Morgenrodel

Henrik Pontoppidans digt "Det lyder som et Eventyr" blev forste gang trykt $i$ "Berlingske Tidende«s julenummer 1918 og få dage efter atter gengivet $i$ \#Flensborg Avis».

Det lyder som et eventyr, et sagn fra gamle dage:

en røvet datter, dybt begrædt, er kommen frelst tilbage!

Eventyrmotivet - billedet af den røvede datter, der kommer tilbage, efter at der er betalt blodige løsepenge (»seks tusind unge sønners liv«), men som alligevel er fattet og for stolt til at bede om medlidenhed - er så enkelt og 
letfatteligt, at det umiddelbart og øjeblikkeligt gled ind i den danske forestillingsverden som det klassiske billede af Sønderjyllands hjemkomst efter 56 års prøjsisk styre. Maleren Joakim Skovgaard anvendte da også både motivet og første vers i sin afstemningsplakat, en af de kunstnerisk mest vellykkede og smukkeste af de danske plakater op til afstemningen 1920.

Antallet af faldne er lidt overdrevet, men det kunne Pontoppidan ikke vide på det tidspunkt, idet det næppe var opgjort. En officiel tælling siger 5136 faldne eller ca en sjettedel af de omkring 30.000 indkaldte. En del af dem var naturligvis tysksindede, måske så mange som en fjerdedel. ${ }^{2}$

Og endelig var Pontoppidan overoptimistisk, når han i vers to skrev, at »til sommer vajer Dannebrog igen på Dybbøl Banke«, men han kunne jo så lidt som nogen anden vide, hvor lang tid der skulle gå, inden Genforeningen blev en kendsgerning.

Litteraturprofessor Vilhelm Andersen skrev nogle måneder efter digtets fremkomst: "Med de lange umelodiske linier klinger det, som om en, der ikke er vant til at synge - denne digters kunst er ikke verset, men prosaen - gav sig til at nynne, fordi han bevægedes af en stor glæde, sådan som den, der ellers ikke synger, dog synger salmen med juleaften. $\aleph^{3}$

Da sangen første gang kom i bogform, var 3. strofe (om »løfteord af frænder« på både dansk og tysk) strøget efter digterens anmodning (vel af politiske grunde - Pontoppidan ønskede sikkert ikke på det tidspunkt at blive taget for tyskvenlig!), men det er heldigvis senere medtaget $\mathrm{i}$ sangbøgerne, da det er værdifuldt for forståelsen af tankegangen. ${ }^{4}$

Henrik Pontoppidan var normalt ikke en national - endsige nationalistisk digter. Tværtimod er han det danske folks store revser, og måske netop derfor virker hans strofer så ægte, at de har overlevet og stadig synges.

Det samme kan ikke siges om Valdemar Rordam. Han var dog ellers datidens mest konsekvente dyrker af det danske med næsten religiøse undertoner, og i afstemningskampen stillede han sig fra første færd på den linje, der krævede Sønderjylland til Ejderen: "Ikke blot landet, også folket indtil Danevirke, hører sammen med os den dag i dag, - og er i færd med at opdage det, « skrev han $1919 .{ }^{5}$ Og samtidig bød han sønderjyderne velkommen hjem:
Velkommen, kære venner,
i Danmarks frie gård, hos flaget, som I kender, hos folk, som I forstår! ${ }^{6}$

I digtet »Sværdet på Dybbøl kirkegård «, der er dateret november 1918, brugte han et tysk krigsmindesmærke ved Dybbøl kirke som symbol på tysk volds- 


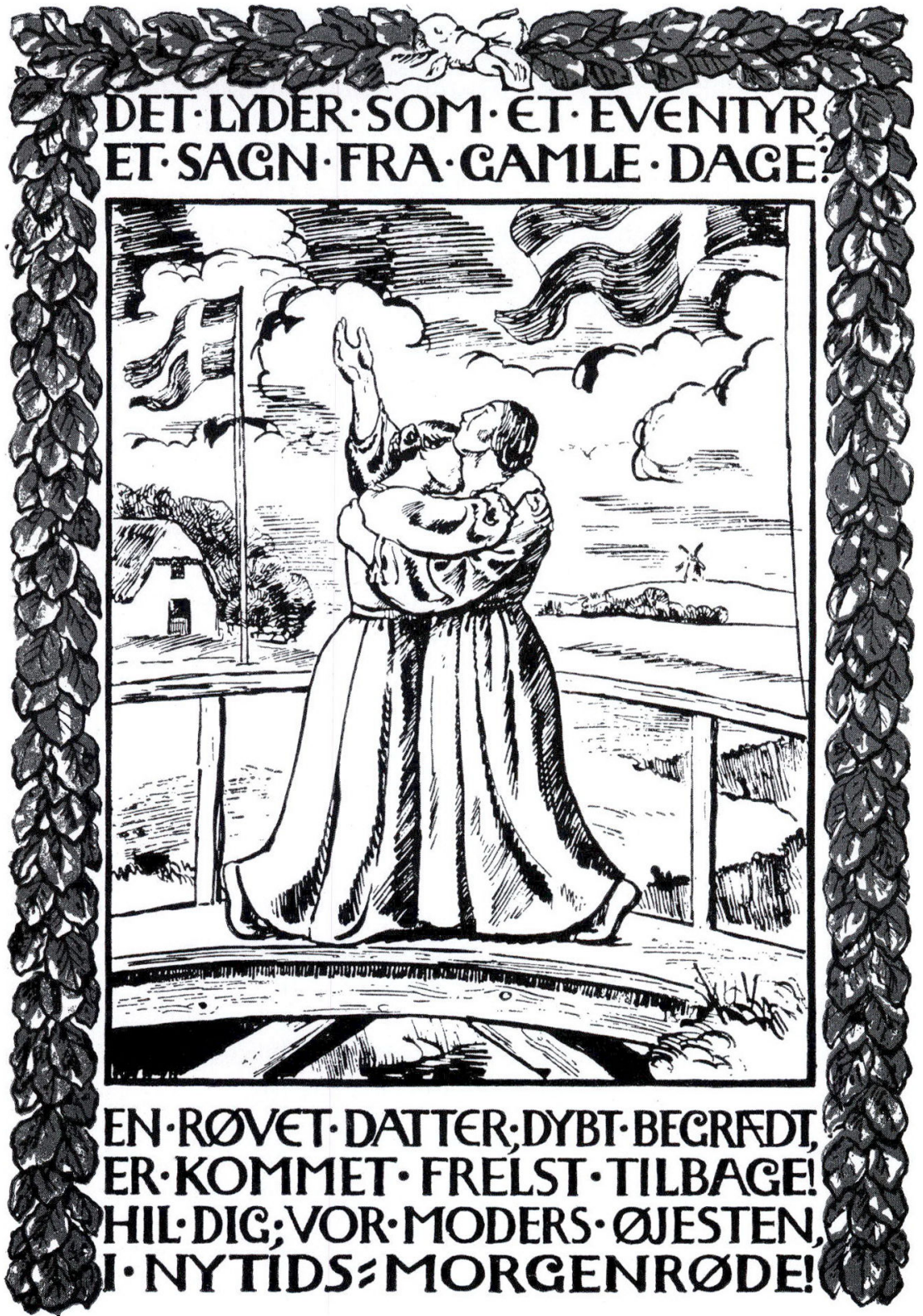

Joakim Skovgaards plakat med 1. vers af Pontoppidans genforeningssang viser Danmark som en varm og frodig moderskikkelse, der modtager den rovede datter på broen over Kongeden. Den er flankeret af en dansk bondegård og molle, og Dannebrog er hejst på begge sider. Ingen kan vare $i$ tvivl om budskabet: landet er dansk bdde nord og syd for den gamle granse. 


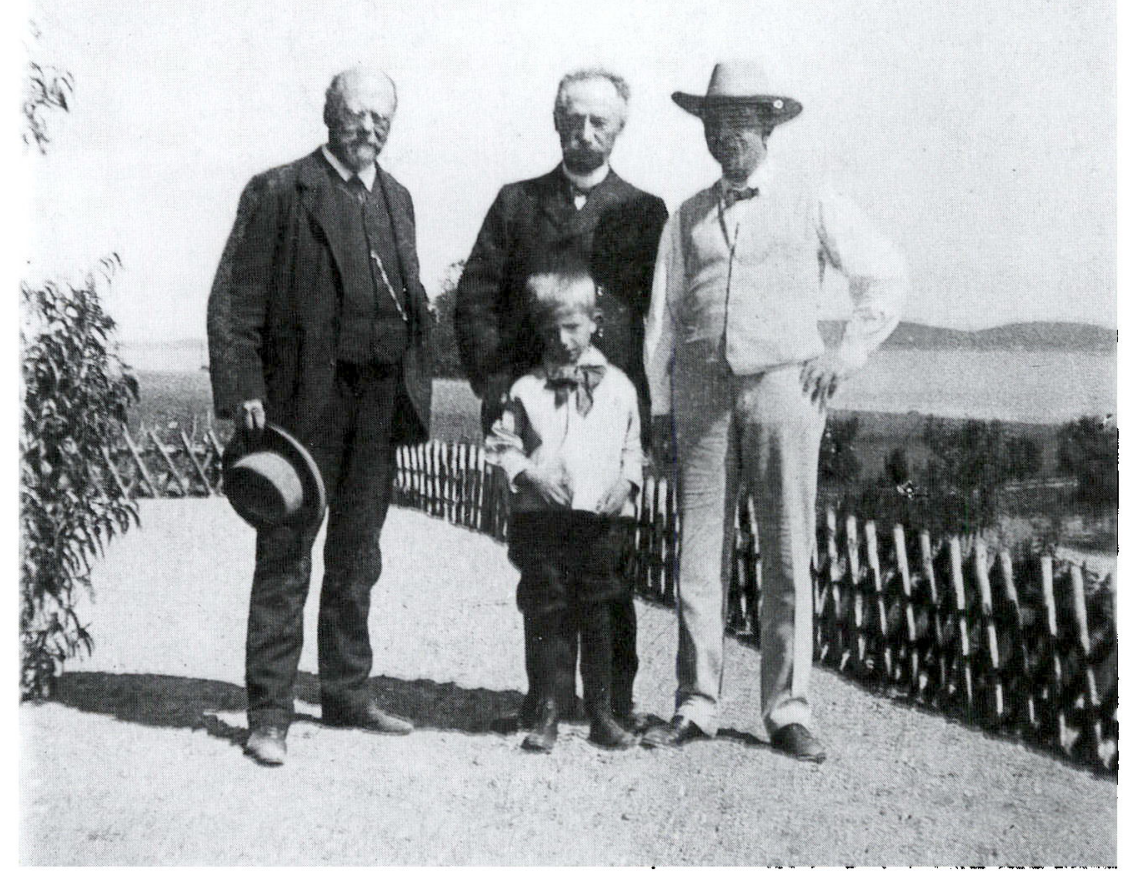

Valdemar Rørdam (1872-1946) var kendt som en noget svulstig, men teknisk meget dygtig lyriker, hvis digte om naturen, karligheden og fadrelandet vandt et stort publikum. I afstemningstiden 1919-20 kravede han Danmark til Ejderen. Blandt hans kendteste digte er sangen »Danmark $i$ tusind år. Som ultrakonservativ nationalist og militarist meldte han sig i 1941 under det danske nazist-partis faner, vel narmest i frustration over den efter hans opfattelse manglende danske forsvarsvilje, der havde resulteret $i$ besattelsen 1940. Rordam ( $i$ lyst sommertoj) er her sammen med grosserer Poul Plum (yderst til venstre) på besøg hos redaktor Jens Jessen på Fjordmark ved Flensborg fjord. Foto 1905 i Dansk Centralbibliotek for Sydslesvig.

magt. Gravstenen var prydet med et stort bronzesværd, som fjernedes efter befrielsen 1945 af frihedskæmpere, som var lidt sent ude:

men lad det sværd da stå med al sin trods

mod freden og de faldne og mod os!

Thi sandt er tegnet, evig er den trussel. ${ }^{7}$

Flensborg var for ham hovedmålet. Til en festaften i Koncertpalæet i København den 22. januar 1919, hvor bevægelsen for en sydligere grænsedragning end den, H.P. Hanssen og hans folk gik ind for, startede sin kampagne, skrev han en sang, hvori disse linier, der fremholder naturen og de danske minder som noget helligt og ukrænkeligt, forekommer: 
Kæmpegrav, grænseby, købstad og fjord, favnet af hellige heder, plattysk og dansk $i$ et broderligt kor aldrig, hvor langt vi end leder, ser vi så kostbar en troskab i nord som hos Eder! ${ }^{8}$

Man vil samtidig bemærke, hvor langt mere mundret Pontoppidans enkle vers er end Rørdams svulstige og kunstfulde patos, som vi i dag har svært ved at tage helt alvorligt.

I en række artikler fra en rejse i Sønderjylland i sommeren 1921 bebrejdede han sine landsmænd i hårde vendinger, at man ikke besøgte det genvundne land, så hoteller og kroer langs Flensborg Fjord stod tomme(!), og - med et noget større perspektiv - bittert begræd, at grænsen ikke var rykket langt længere mod syd. Det kneb somme tider for Rørdam at holde de store og de små ting adskilt. Men han glædede sig dog også over, hvad der var vundet:

"Men så vajer nu det røde og hvide korsflag frit i Brøns og Bredebro, i Skast og Møgeltønder; og øst ovre, i Kollund og Rønshoved ... « Og syd for Frøslev ser han flaget »over en usynlig gård, en af de tre fra Ellund, som vi fik med over.

De har stærkere lys og dybere glød, disse flag, end de andre, fordi de står langs med den ny grænse. De taler om, hvad der er vundet, hvad der endnu er tabt. Ingen af delene tor vi glemme.. ${ }^{9}$

I den store cyklus "Sangen om Danmark «, skrevet til kong Christian Xs og dronning Alexandrines sølvbryllup 1923, glædede han sig dog ubetinget over det Sønderjylland, der kom tilbage til Danmark ved Genforeningen og mindedes festen på Dybbøl:

... hvor de og vi den sommerdag

så kongen kysse Danmarks flag,

der genrejst af sit nederlag

favntog folkets møde

med sin jord og sine døde. ${ }^{10}$

\section{Få store og mange små poeter}

Da de første sønderjyske krigsfanger i marts 1919 kom til København, holdtes en fest for dem på Københavns Universitet, hvor bl.a. den senere biskop i Haderslev, professor Valdemar Ammundsen, talte. Festen indledtes med uni- 
versitetsbibliotekar Carl Dumreichers sang "Hilsen«, hvori han omtalte det tabte Sønderjylland som »et felt med sørgeflor«, som nu fik flagets farver:

Der var i Danmarks våben et felt med sørgeflor.

Der stod i Danmarks ager et dybt og fremmed spor.

Der var i Danmarks hjerte et altid åbent sår, -

Men aldrig gik et forår over Danmark som i år.

For floret har vi byttet for flagets farver bort, og bødet bliver flængen i Danmarks gamle kort. ${ }^{11}$

Dette sidste vers fik Vilh. Andersen til lidet respektfuldt at mene, at det $\gg$ i øvrigt giver et andet billede for øjet - fra landsbyskolens væg - end digteren vistnok havde tænkt sig. $\aleph^{12}$

Digtet indgik i den kantate, "Til landsmænd sønden å«, som Dumreicher året efter skrev til musik af Peder Gram i anledning af Genforeningen. Han lod sønderjyderne se mod »bakkekammene mod nord, / der gemte hjertets håb«, som nu er tændt igen:

Dér spærred pæl - dér standsed strøm, når troen ville frem.

$\mathrm{Nu}$ lyser gryets gyldne drøm

bag Kongeå os hjem.

Han priser Danmarks natur, der bliver et billede på moderen:

Vi ser dig, Danmark, som et syn bag tågen;

dit moderblik holdt sønnens vilje vågen.

Hvor fjernt vi gik, dit milde billed' fulgte,

og på vor kistebund dit flag vi dulgte.

Men bag glæden ligger sorgen over de mange, som faldt i krigen, og som "usynligt ... er med ... i alt, som omkring os sker«, og af dem skal vi lære merindringens hellige stunder « at kende. ${ }^{13}$

1920 udgav Dumreicher efter opfordring af forlagsboghandler Oscar Gad en bog om "Genforeningen 1920«, hvori han skildrede genforeningsdagene, som de formede sig såvel i København som i Sønderjylland. Han bringer både taler og sange fra de officielle fester. Kort efter at kongen havde underskrevet "Loven om Indlemmelse af de sønderjyske Landsdele« om formiddagen den 9. juli, afholdtes en festgudstjeneste i Frue Kirke, hvortil provst Henry Larsen 
fra Skamstrup-Frydendal ved Holbæk havde skrevet en sang. Han mindedes de faldne, men fortsatte trøstende, at

spired dog fremtidens friske frø

der, hvor du så dine sønner dø.

Efter prædikenen sang man en sang af den nyligt afdøde oberst $A$. Levinsen:

Lovet være Gud, som tog og som gav tilbage.

Samme dags eftermiddag holdt De danske Soldaterforeninger en fest, hvor bl.a. kongen, Christian X, talte. Ved denne lejlighed foredrog kongelig kammersanger Peter Cornelius en sang digtet af Th. Calberg, som i øvrigt er mig ubekendt. Han fæstnede sig især ved Sønderjyllands betydning i Danmarkshistorien:

Hil dig du land bag Søndenå, du gamle Danmarks skønne have, hvor minderne på vejen stå og tale højt om heltegrave; hvor kongeættens vugge stod ...

I de følgende vers taltes der om »kamp og strid«, »rets tunge åg«, »heltemod mod overmagt«, »liv og blod «, og »landsoldaten, (der) løftet holdt«, og andre stærke sager. ${ }^{14}$

Efter festen sejlede kongen fra København til Sønderjylland med kongeskibet »Dannebrog«, som fulgtes af krydseren »Heimdak og tre torpedobåde. Da skibene havde lagt fra kaj, holdtes friluftsfester for de tilbageblevne i Rosenborg Have og Tivoli, og begge steder sang man sangen "Vi vil hjem« af A. C. Bille-Hansen, der var ekspeditionssekretær i Kabinetssekretariatet. Heri mindedes han sønderjydernes udlændighedstid og krigens tunge ofre, og der var ikke sparet på klichéerne:

Nu er dagen, vi vented', oprunden, og til ende er trængselens tid.

Se den trælsomme vinter er svunden;

fremad skrider skærsommeren blid.

Hør der brusende kor!

Hør de jublende ord:

Vi vil hjem til vor egen gamle Mo'r. ${ }^{15}$ 
Af nogenlunde samme poetiske lødighed er den sang, som Gudrun Jarnøe skrev, og som med musik af Johs. Andreasen fik en vis udbredelse i afstemnings- og genforeningstiden. Symboler og metaforer er gammelkendte og bombastiske, og rytmen kunne være bedre:

Vingeskudt og blodig ligger den tyske ørn,

Danmark, vor gamle moder, samler igen sine børn.

Tåren vil hun standse, hun jo forstod det bedst, børnene, som led ilde, står moders hjerte næst. ${ }^{16}$

Dumreichers »Hilsen« blev sammen med »Det lyder som et eventyr« og Rørdams Flensborg-digt optaget i samlingen "Danske Fædrelandssange«, som Dansklærerforeningen udgav i sommeren 1920. Den var redigeret af seminarielærer Ingeborg Simesen, der i årenes løb stod for adskillige af Dansklærerforeningens udgivelser af danske klassikere. Hun skriver i forordet, at hun især henvender sig til »dansklærere og sanglærere, som det påhviler at hæve denne sangskat, ... hvis nationale værdi ikke kan regnes højt nok; en levende fædrelandssang vil altid vække en levende fædrelandskærlighed og omvendt.« Hun håber derfor, at bogen "må blive dem et hjælpemiddel $\mathrm{i}$ kampen for et stort mål.« Det har været hende selv »til patriotisk opbyggelse ... at sysle så indgående med vor nationale sangskat på baggrund af det sidste års begivenheder, « og derfor håber hun særligt, at »den vil finde vej ind på seminarierne, hvor fremtidens dansklærere opdrages til at gøre deres store gerning ude i det danske folk.« Der er således ingen tvivl om formålet med bogen: fædrelandssangene skal være et led i den patriotiske opdragelse af den danske ungdom. ${ }^{17}$

Foruden de tre nævnte sange var også historikeren og museumsmanden Jørgen Olriks digt "Skamlingsbanken«, dateret 1. januar 1919, optaget i bogen. Skamlingsbanken betegnes som stedet, hvor »folkets samlingstanke« skal ytre sig i »ord og sang«. Herfra kan man »skue .../ viden ud mod alle vinde,«

... men mod syd må øjet dvæle tungt ved grænsepæle.

Men som det gik støtten på Skamlingsbanken, der blev sprængt af tyskerne 1864, og som genrejstes efter krigen, vil det også gå Sønderjylland:

Danske dog den atter rejser, så fra top påny den knejser.

Varsel tør vi af den tage:

Slesvigs land tilbage! ${ }^{18}$ 
Journalist Anders Diemer, der var født i Abild, og som 1920 blev adjunkt på Haderslev katedralskole, skrev i foråret 1919 digtet "Nu kommer de tilbage«, hvori han giver udtryk for en nærmest ekstastisk glæde over udsigten til den kommende genforening. Flag skal flyve, klokker ringe på denne glædens dag. Dette må kunne samle alle danske:

Nu kommer de tilbage! Ring, klokke, over land, kald barnet bort fra legen, fra sit arbejd hver mand!

Nu kommer de tilbage. Så grav da kævlet ned! Lad os enes! enes alle! Blot en stund holde fred!

Sønderjyderne har stridt for at få lov til at være danske, og til sidst måtte de med i krigen. Det opfattes næsten som et offer, der belønnes:

Kun Gud ved, hvad de led. Men han hørte deres bønner.

Så forunderlig velsignet deres trofasthed han lønner.

Og derfor skal Danmark klæde sig i festdragt og byde dem »velkommen tilbage«. De skal rigtigt mærke, at »nu kommer vi hjem!«, så de sammen med resten af landet kan skabe en forhåbentlig lys fremtid. ${ }^{19}$

Også den nørrejyske digter, lektor ved Viborg katedralskole Niels Jeppesens digtsamling »Slesvigs sønner « er skrevet på forventningen om Genforeningen og sorgen over verdenskrigens faldne. Men henvisning til Brorsons salme »Her vil ties, / her vil bies« slår han tonen an:

\author{
I har tiet, \\ I har biet \\ bag de sorte grænsepæle \\ indtil nu, da I fik mæle \\ i udlændighedens år.
}

Ofte har der været kæmpet om Slesvig, men sønderjyderne »stod som Danmarks vold«, og nu har de måttet gennemlide krigens trængsler for Tyskland. Han svinger sig op til de meget patetiske højder, når han hylder de sønderjyske soldater, der i »det store marterfængsel« (verdenskrigen) »med Dannebrog for øje« (!) »vandred ud at lide« for at frelse Danmark, blive »Danmarks bod «, som han siger med Kocks ord fra Dannevirkevisen.

I det store digt »Spandet« mindes han i glimt fra slægtens hjemsogn livet under prøjsernes styre med forfølgelse, fængsling og forjagning. Han omtaler 
bedstefaderens tro på, at landet atter ville blive dansk, og skolelæreren, der bliver afskediget, fordi han ikke ville straffe børnene, som jublede ved en (falsk) meddelelse om kejser Wilhelms død. Han beretter om den forjagede præst, der ikke må deltage i hustruens begravelse, og om gårdejer Mads Vind og hans datter, der blev angivet af en falsk flygtning, da de hjalp dansksindede sønderjyder med at komme over grænsen under krigen, så de kunne slippe for at skulle tilbage til slagmarken.

Bismarck-statuens fjernelse fra Knivsbjerg ser han som et sikkert tegn på, at Genforeningen er nær. Og når om kort tid hele landsdelen er dansk, skal sønderjyderne, som altid har været rigets forpost, med deres dyrekøbte erfaringer hjælpe Danmark til en bedre fremtid:

Slesvigs sønner, som i ord og dåd altid hegned Danmarks åbne have, giv os jer, og giv os vise råd, når I flytter grænsens sorte stave! ${ }^{20}$

Den verdensberømte litteraturforsker og kulturhistoriker Georg Brandes, måske Danmarks mest berømte person på den tid, udsendte en samling ældre artikler om "Sønderjylland under prøjsisk tryk «, skrevet 1899-1905, forsynet med et forord om hans eget forhold til landsdelen - hvori han, vanen tro, ikke stillede sit lys under en skæppe - og en ret intetsigende kommentar: "Tyskland er blevet et andet land, Danmark vil næppe kunne forblive uforandret, de nationale kampe, der indtil nu har rystet Europa, vil smelte sammen med de sociale, hvis voldsomhed ikke synes at blive mindre stærk. $^{21}$ Det kan måske umiddelbart se ud som en (lidt for) optimistisk forventning om, at Europas nationale og sociale modsætninger er på vej mod en udjæuning. Men så naiv var Brandes næppe.

Gyldendal genudsendte digteren Holger Drachmanns skildringer fra 1877 »Derovre fra grænsen« i en såkaldt »Genforeningsudgave« med forord af digterens søn, forfatteren, cand. polit. og senere folketingsmand Poul Drachmann. Det er heri, man finder det kendte digt $" D e$ vog dem, vi grov dem / en grav i vor have, / lagde dem ved siden af den alfar vej« om soldatergraven fra 1864 i Bøffelkobbel med de hysteriske linjer:

Nej, heller vi os vier til den døde soldat; søster, hør efter, hvad vi siger!

Lad tøjterne ved Elben være tysken parat:

Enker er de sønderjyske piger! 


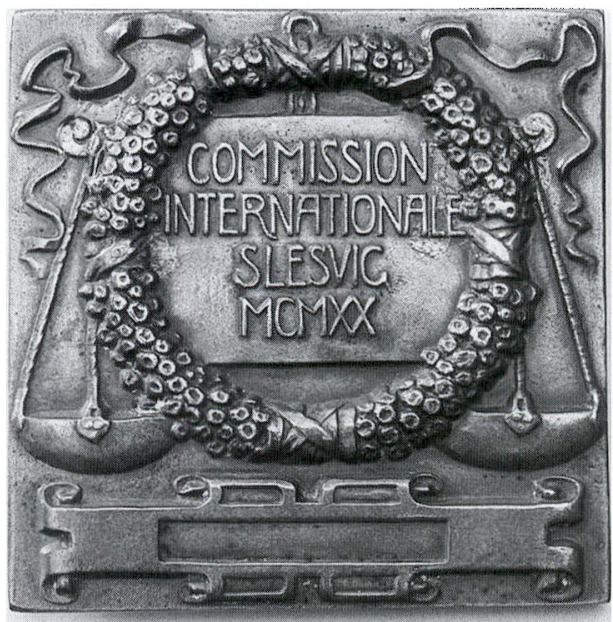

For- og bagside af plakette uddelt af Den internationale Kommission i 1920 som tak til personer, som havde hjulpet $i$ afstemningstiden. P\& forsiden symboliserer yagten den retfardighed, som afstemningen skulle muliggore. Bagsiden kan stå som pendant til ordene i grev Schacks og Valgerforeningens opråb:

Om dette digt skrev Ingeborg Simesen, at det er »et gribende (!) udtryk for frygtens og tillidens stadige kamp i sindene »derovre«« d.v.s. i Sønderjylland. ${ }^{22}$

Digterens søn var enig med hende. Når bogen nu genudsendtes, 42 år efter dens første fremkomst, havde den, skrev Poul Drachmann noget svulstigt, en "mission, der ikke blot får vægt af den jubel, der ligger i synernes virkeliggørelse, men som også byder os at spejle os i fortidens store spejl, gøre op med vore dyder og mangler og ordne vor nutid og planlægge vor fremtid i pagt med de bedste kræfter. Og hertil vil vi - som enhver nation overhovedet - have at lytte til sangeren, som udløste de inderste og kernesunde tanker i vort folk, som selv bar ved på nationens bavne i modgangens mørke, fordi han havde den store tro, som er ethvert folks livbetingelse. $\ll^{23}$

Verset om »tøjterne ved Elben« og de sønderjyske enker er godt at have in mente, når man læser om Holger Drachmanns »kernesunde tanker«, der er et "gribende udtryk for frygtens og tillidens stadige kamp i sindene«!

Johannes $V$. Jensen synes ikke at have gået særligt op i afstemningstidens begivenheder. Men et par strofer i digtet "Transfiguration « (Forvandling) kan hentyde til Sønderjyllands genforening og det tyske kejserriges undergang: »Ind i himlen stiger syngende lærken«: 


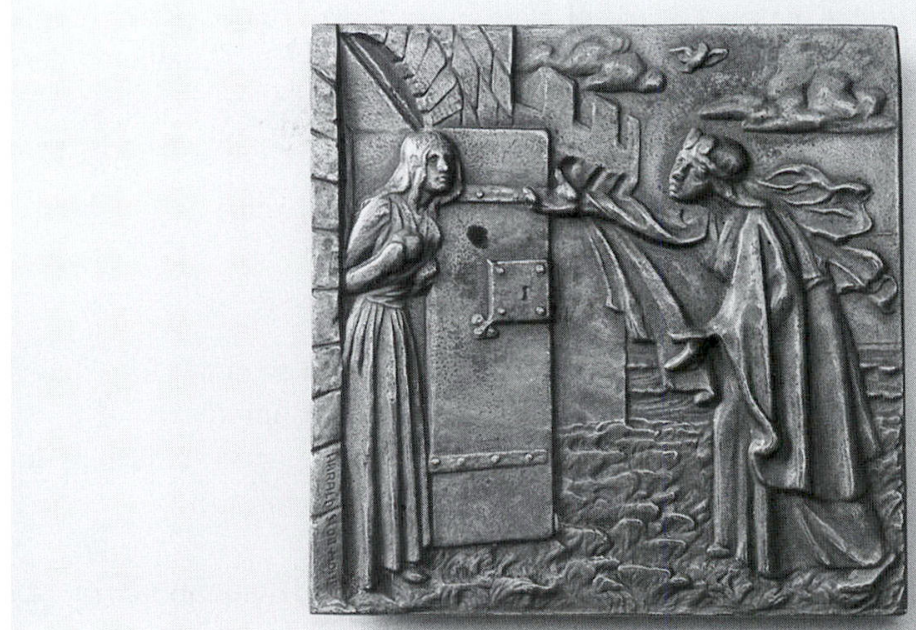

"Man har givet os noglen $i$ hande til den läsede dor, mod hvilken vi har hamret $i$ et halvt ârhundrede men vi må selv lukke doren op!« Original i Arkivet ved Dansk Centralbibliotek for Sydslesvig. Foto: Helge Krempin.

Hørte du vor zone
tone?
Vældig solen skrider,
rider
over rum og tider.
Bi, bi, bi!

\author{
Under dig i dybet \\ krybet \\ sortner i sin larve. \\ Arve \\ skal du lys og farve! \\ $\mathrm{Bi}, \mathrm{bi}, \mathrm{bi} !^{24}$
}

Man må uvilkårligt sammenligne med skolemanden, dr. phil. og borgmester i København Ernst Kapers beskrivelse af Dybbølfesten, hvor han midt i gengivelsen af grev Schacks tale, da denne nævner »Dybbøllærken«, skriver: "Taleren standsede betaget et øjeblik. Højtidsstilhed som $\mathrm{i}$ en kirke lå over de mange tusinder. Oh hør! Et brus af jublende lærkesang tonede og klang over vore hoveder «. ${ }^{25} \mathrm{Og}$ så er Kapers ord og Johs. V. Jensens digt i øvrigt forsynet med næsten identiske vignetter af den fynske maler Johannes Larsen.

Vælgerforeningens opråb til sønderjyderne om at møde frem og stemme, som grev O.D.Schack fra Schackenborg forfattede, og som på H.P.Hanssens anbefaling blev vedtaget på Vælgerforeningens tilsynsråds møde den 15. september 1919, er i sig selv som et prosadigt, klart og associationsrigt, hårdthugget i formen. Der er dækte verselinjer af Bjørnstjerne Bjørnson fra 
Norges nationalsang »Ja, vi elsker dette landet« (»Alt, hvad fædrene har kæmpet, / mødrene har grædt, / har den Herre stille lempet, / så vi vandt vor ret«) og et citat af den sønderjyske politiker Nicolai Ahlmann, der i 1867 i den tyske rigsdag i Berlin udtalte: $» \mathrm{Vi}$ er danske, og vi vil vedblive at være danske. Vi vil behandles som danske, og det efter folkerettens principper«:

\section{Sonderjyder!}

$\mathrm{Nu}$ er dagen der, vi vil hjem!

Hvad slægtled har troet på, fædrene kæmpet og mødrene grædt for - håbet, der har båret vore sønner over krig og død, skal nu gå i opfyldelse.

Man har givet os nøglen $i$ hænde til den låsede dør, mod hvilken vi har hamret $\mathrm{i}$ et halvt århundrede - men vi må selv lukke døren op!

Ryk grænsepælene op og flyt dem langt mod syd!

Vi er danske og vi vil vedblive at være danske, og afstemningsdagen skal vidne derom for kommende slægter.

I syd og nord, øst og vest i vor landsdel vil vi samles om det fælles mål, skal det lyde enigt som fra broder og søster:

Vi vil hjem, hjem til Danmark! ${ }^{26}$

Jeppe Aakjær sad på gården Jenle i Salling og så »fræ wor søndle rud « (fra vinduet mod syd) mod Sønderjylland og glædede sig over, at folkemålet holdt stand mod fortyskningen, trods forbud og forfølgelse:

... Trods wand-og-brød og mulkt og skrol, proces og bank i skuel og skrank

- den flytt sæe ett en flyk!

Bl.a. fordi de var trofaste mod deres danske sprog, som »er hwerken plat hæ tysk, / (men) ... redle wæjmelsjysk «, byder han sønderjyderne "»)Goddaw ijen!« po gammeljysk $-\ll{ }^{27}$

\section{»I skal ikke blive glemt!«}

Digteren, cand.jur. Kaj Hoffmann, der var assistent ved kriminalretten i København, er mest kendt for sangen "Den danske sang er en ung blond pige«. I anledning af folkeafstemningerne i 1.zone 10 . februar og i 2.zone 14. marts 1920 og Genforeningen skrev han en hel stribe digte: 
Ingen drøm er drømt som denne, mere skøn var ingen drøm -:

Atter et de skilte tvende, atter dansk den danske strøm folk og land, med eng og fjord, udelt et fra syd til nord!

Foråret 1919 bliver symbolsk for ham. Vejret i Sønderjylland er det samme som i resten af landet, og selv forårsarbejdet på marken vidner om forbindelsen nordpå, og at landsdelen nu skal hjem til Danmark:

$$
\begin{aligned}
& \text { Vender en plov nu mulden } \\
& \text { ved Løgum eller Tønder - } \\
& \text { så er det sæden nordfra } \\
& \text { og ikke en sæd fra sønder. }
\end{aligned}
$$

Hans jubel kender ingen grænser:

Så velkommen i solskin og sommer

og velkommen $\mathrm{i}$ forår og høst, så velkommen den stund, hvor I kommer vær velkommen i sorg og i lyst ...

Men der er ét usikkert moment, et utrygt skår i glæden. Flensborg. Hvordan skal det gå? For Hoffmann er der ingen tvivl: Byen er dansk, og den skal med ved Genforeningen. Men kan det lykkes? Der må agiteres, og alle må gøre deres, stort eller småt:

\section{Hjælp til, vær med, hver dansker! \\ Hver har sin pligt, sit hverv. \\ Fordømt den mand, der skulker! \\ Velsignet enkens skærv! ${ }^{28}$}

Man mindes, hvad redaktør Tage Jessen (rigsdagsmand Jens Jessens søn) fortalte fra afstemningskampen i 2. zone, hvor præsten i Hjoldelund sagde i sin prædiken den 7. december 1919: »Verflucht seien die Hunde, die für Dänemark agitieren!« (Forbandet være de hunde, der agiterer for Danmark). ${ }^{29}$ Forbandelser over dem, der »svigtede«, blev udtalt fra begge sider.

Men selv om det kniber, så er Hoffmann - trods alt - fuld af fortrøstning. Det kan ikke gå galt! Det må, det skal lykkes: 
Tyskland kan tage en nordisk by

og gøre den tysk.

Flensborg - den stad, som i tusinde år

var sønderjysk -

kan dog vel skifte igen, og påny

stemme for Danmark som danskernes by.

Han har kun hån til overs for dem, der maner til forsigtighed. Det er der ingen grund til. Tyskerne vil, uanset hvad vi gør, være en trussel, siger han. De er næsten pr. definition vore fjender. Men denne gang må de ned med nakken:

»Tys, forsigtig, husk dog, ven -

de kan rejse sig igen!«

$\mathrm{Ja}$, tilvisse - sande ord.

Evigt truer syd vort nord.

Men for store ting er hændt.

Slukte lys er pragtfuldt tændt.

Han søger - næsten febrilsk - at mane det tyske flertal i byen bort:

... vi vil nynne på en sang

om en trold, som var engang.

Men da afstemningens dag i 2.zone (14.marts 1920) endelig stod for døren, følte Hoffmann sig afmægtig. Nu var der kun ét at gøre: at håbe på Gud. Han synes helt at glemme, at det er den samme Gud, man tilbeder nord og syd for Skelbækken, blandt tyske såvel som danske. Men med fortrøstning $\mathrm{i}$ sagnet om den gamle arkebisp Anders Sunesøn, der bad i slaget ved Lyndanisse 15.juni 1219, og som til sidst blev så træt, at nogle munke måtte holde hans arme oppe, for at han kunne blive ved, til Gud havde givet danskerne sejren, opfordrer Hoffmann sine landsmænd til at forsøge denne gennemprøvede metode en gang til. Selv om man nok må sige, at det er en noget tvivlsom logik, han demonstrerer $i$ andet vers, at hvis man virkelig tror, så har man også ret:

Vend dit ansigt mod Flensborg Fjord,

Danmark, i dag og bed!

Bed til den Gud, som er Gud i nord bed, indtil sol går ned! 
Løft dine hænder mod fjerners blå, løft dem og bliv ikke træt.

Så højt mod himlen din tro kan nå, så vidt har du også ret.

Sænker du armen, før sol går ned, så mister du Flensborg by.

Vend dig, Danmark, mod syd og bed bed indtil næste gry!

Under en af svenskekrigene i 1600-tallet - vistnok Den Skånske Krig 167679 - fortælles det, at den danske konge anråbte Vorherre om sejr, men svenskerne var sikrere i deres sag: Deres konge bad nemlig på latin, og det sprog måtte da være Gud nærmere end gement dansk! - Man skulle næsten tro, at Hoffmann levede i den tro, at dansk var Vorherres eget sprog, og at han hellere ville tilbedes på dansk end på tysk.

Men afstemningens tale i Flensborg lod ingen tvivl mulig. Kun en fjerdedel stemte for Danmark. Nederlaget var knusende. Man kan næsten læse i Hoffmanns digteriske kommentar, at det var ventet. At han end ikke selv for alvor har troet på bønnens magt - den danske bøn! - og sin egen besværgelse:

Dertil - og ikke længer.

Herfra og sydpå - tabt.

... Hertil - og ikke længer.

Her ender Danmarks jord.

Danmarks grænse var dog - trods alt - rykket sydpå, og det trøster han sig med, selv om det er med dyb skuffelse over, at ikke endnu mere af Sønderjylland blev dansk. Og han søger at trøste dem, der »blev tilbage« - »de skal ikke blive glemt«, som statsminister Niels Neergaard formulerede det i sin tale på Dybbøl 11.juli 1920:

Du danske ungdom i Flensborg by, så lidt som du kan din moder glemme.

Hun glemmer ikke hint skær af gry,

hun hører altid din fjerne stemme -

Du Danmarks ungdom i Tysklands by!

Men Nordslesvig havde stemt sig hjem. Genforeningsdagen den 10.juli oprandt. Kongen red over den gamle grænse. Alt var fest, flag og farver: 
Danmark flytter sin grænse.

Det er i dag, det sker.

Et Danmark syd for Danmark

er ikke syd for mer.

Men selv midt i glæden græmmedes han. Jubelen »standser ved Flensborg Fjord.« Den nye grænse lod sig ikke rokke. Den lå fast.

Fjender er fjender, og det vil de altid blive, skriver Hoffmann. De skal holdes på lang afstand, mens vi samles om det, som er vort (og kun det!):

Vi skal elske kun det, som er ånd af vor ånd -

kun den nordiske mand.

Og vi hilser med opstrakt og sværgende hånd

Nor, Svea og Dan! ${ }^{30}$

Man skal vist glæde sig over, at socialdemokraten (!) Hoffmann næppe selv vidste, hvad han sagde. Og hvilke mørke kræfter, disse dystre profetier kunne mane frem. På det tidspunkt havde allerede en gruppe frustrerede tidligere frontsoldater i München dannet Det Nationalsocialistiske Tyske Arbejderparti (NSDAP), hvis medlem nr. 7 hed Adolf Hitler. De fandt ret snart ud af at »hilse med opstrakt og sværgende hånd « og tro på den nordiske ånd.

Hoffmann var ikke nazist, overhovedet ikke, men hans frustration over nederlaget i 2. zone og især tabet af Flensborg fik ham til at sige ting, som ville falde på plads som handske til hånd i en nazistisk ideologi.

En lignende tone, blot endnu mere skinger, anslås af bibliotekar, dr.phil. Viggo J.von Holstein Rathlou, som i 1919-20 skrev en lang række digte med det formål at rejse en stemning for en grænsedragning ved Ejderen:

Selvfølgelig går Danmarks ret til Rensborg; men modet - ? Ak, det standser foran Flensborg.

Tyskerne beskrives som »voldsmænd «, »en straffet tyv«, der farer »frem med had og vold og uret«, men som må aflevere det stjålne:

Nej, tyven slippe bør den stjålne skat!

Er det ej ret, så kald først dag for nat!

Han håner de danske politikere og embedsmænd, personificerede i statsminister C. Th. Zahle og »tabelværksmanden«, nationalbankdirektør Marcus Rubin, der manede til mådehold. von Holstein Rathlous særlige fjender er magister 
Viggo J.von Holstein Rathlou (1885-1965) blev 1917 dr.phil. p\& en afhandling om Thomas Kingo. Han var bibliotekar ved Statsbiblioteket $i$ Arhus og 1921 25 leder af Flensborghus Bogsamling, forloberen for Dansk Centralbibliotek $i$ Flensborg. Han var starkt nationalchauvinistisk indstillet og kravede 191920 gransen rykket til Ejderen. I 1920 'erne udgav han to bind agitatoriske og folelsesmassigt overskruede "Slesvigske Digter. I 1930'erne meldte han sig ind $i$ nazistpartiet, hvor han fik status som en slags officiel digter of festkantater og lignende og som Frits Clausens hofpoet, der hyldede foreren $i$ svulstige vers.

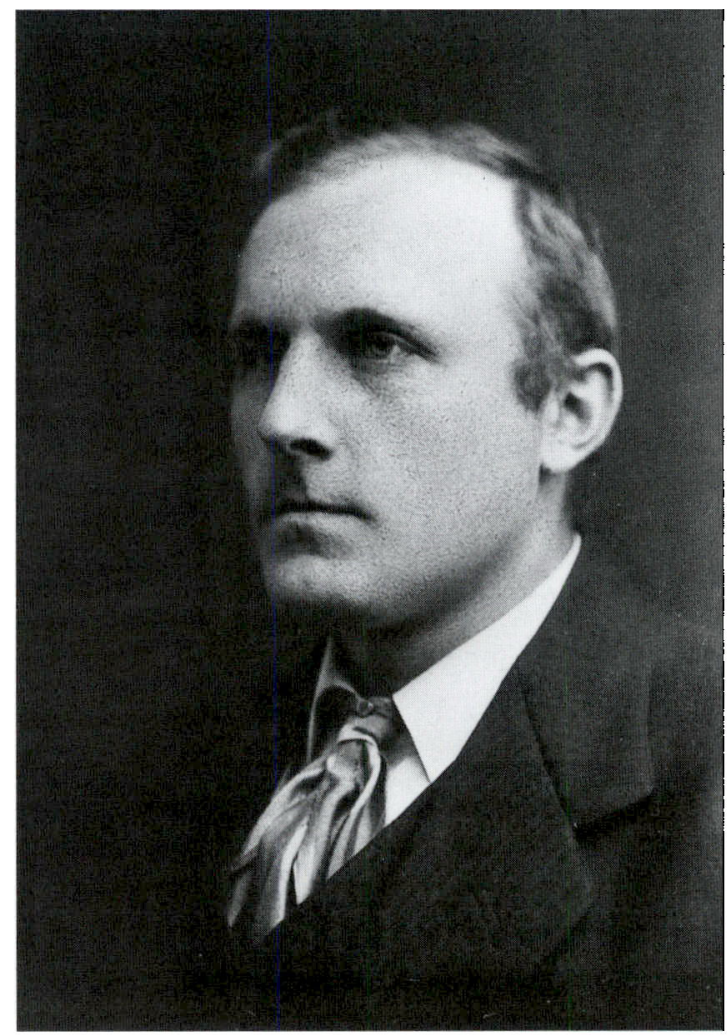

H. V. Clausen, der fastlagde grænsen mellem 1. og 2.zone ud fra sit kendskab til befolkningens nationale holdning, og H. P. Hanssen, der gik ind for denne linje. Han kalder dem for »tysker-elskende«, »forræddere« og »troløse«, der »opgav håbet«. Og han anvender det stærkeste skældsord, han kan få i sin mund, om H. P. Hanssen: en »hjemlig radikal«, og Rubin er en »radikal vendekåbe«! Og når man endelig hører noget fra de danske politikere, så er det

hvad vi orker:

det er det danske folk, der kæmpe-snorker!

I stedet hylder han de mænd, der gik ind for den sydlige grænsedragning, bl.a. Kloppenborg-Skrumsager og "Flensborg Avis'« redaktør Ernst Christiansen, der omtales som »den blonde dansker, groet af Slesvigs jord «, der "går støt i Jessens djærve spor«.

Efter afstemningerne bruger han mange grove ord om dansk »forræderi« 
og svigtende mod, og han trøster og opmuntrer "forposterne « syd for grænsen, ligesom han fremholder "Dybbølløftet« som Danmarks forpligtelse over for landsmændene i Sydslesvig - og over for »os selv«. Det er faktisk værre for danskerne nord for grænsen end for sydslesvigerne, hvis vi ikke holder ord:

"I skal ikke blive glemt!«

Det har os forpligtet.

Mest det for os selv var slemt, om vort ord vi svigted.

Og da han føler, at løftet ikke bliver holdt, som han mener, det burde, skriver han harmfuldt:

O Danmark, har vi da fortjent

at mødes af din kulde?

Har vi ej stået tro på post

og kæmpet, som vi skulle,

på ensom vagt

mod overmagt,

mod had og hån og tysk foragt? ${ }^{31}$

Dette sidste digt blev oprindelig offentliggjort i »Flensborg Avis« 1924 med signaturen "En dansker i Flensborg«. von Holstein Rathlou var indtil 1925 leder af bogsamlingen på Flensborghus, forløberen for det danske centralbibliotek i Flensborg. 1925 genoptrykte han det i hæftet "Slesvig, vort elskede omstridte land «. ${ }^{32}$

Redaktør Hans Henriksen fra Venstres Pressebureau, der også var en flittig digter, udsendte en digtkreds om Genforeningen (i samlingen »Folkets mænd «, 1920), hvor han indleder med folkemødet i Aabenraa den 17. november 1918. Det var her, H.P. Hanssen for første gang kunne give sine landsmænd meddelelse om den kommende afstemning. Og for Henriksen var det, som sprang blomsterne ud midt $\mathrm{i}$ efterårets slud og kulde:

Hvilket under! Det blomstrer blandt frostfældet løv, mens mod midvinters mørke vi går.

Og der gløder et gry med befrielsens fryd bag de bitre og blodfyldte år.

Han takker sønderjyderne for deres trofasthed og tålmod. Fremtiden tegner sig lys og skøn. Fængslet er sprængt, og verden åbner sig. For at give sine følelser 
ord, må han ty til salmerne og den gamle veltjente vise "Danmark dejligst vang og vænge« om Dronning Thyra, der byggede Dannevirke og bragte »ledet i lave«:

... Nu modnes den store frelsensstund, da led skal hænges i lave.

... Til drømmens store vidunderland

slås gyldenporten os åben.

Julen 1919 er en forventningens tid:

Den sidste jul før gensynstimen slår, den sidste vinter før den store vår.

Vinteren 1920 er afstemningernes tid. Hans Henriksen melder sig som Kaj Hoffmann og mange andre i Flensborg-folkenes rækker. De faldne fra fortidens krige rejser sig af gravene og venter på afgørelsen - og håber på sejren ved afstemningen:

Nys ørnens knækkede vinge sank, nu spredes skumringens sky; nu lytter de døde fra Isted Hede; er morgenen tændt påny?

Afstemningen i 1.zone gav det forventede og glædelige resultat, at Nordslesvig stemte sig hjem til Danmark. Den »forpjuskede« tyske ørn viger for de tapre og spændstige danske løver - og Henriksen overser elegant, at det danske våben har tre løver, mens det slesvigske (sønderjyske) våben, der anvendes af både danske og tyske, har to. Derfor halter symbolikken en smule:

- De stemte sig hjem til Danmark!

Ja vist! De blev, hvad de var.

Forpjuskede ørne fløj skræmt mod syd, thi frem sprang løvernes par.

Men i 2.zone gik det jo ikke så godt. Danskerne har dog stået sammen og kæmpet mod fjenderne i denne landsdel i århundreder. Her ligger Dannevirke. Har sydslesvigerne da glemt, at de var danske?

Henriksen bruger udtrykket »stortysken«, der skal associere til "stortyrken«, det udtryk, der anvendtes om den tyrkiske (islamiske) fare, da sultanen rykkede mod nord og nåede helt til Wiens porte i 1680 'erne. Der skal ikke herske tvivl om, hvem der er fjenden, og hvad han regner tyskerne for. Og for at give sine ord den rette nordiske vægt, anvender også han Bjørnsons ord om 
walt, hvad fædrene har kæmpet, mødrene har grædt«, de samme linier, som H. P. Hanssen citerede fra »Folkehjem《s balkon den 17. november 1918, og som grev Schack henviste til i sit opråb:

Vi har muret i fællig på virket mod syd, da stortysken rykked os nær;

og med skulder ved skulder med skærpede spyd, har vi stridt imod vendernes hær.

... Og det spørger så tyst, i stilfærdige ord: Har I glemt, hvad vi sammen har stridt?

Alt, hvad fædrene kæmped i tider, der fo'r, og hvad mødre har længtes og lidt?

Efter at have budt de hjemvendende velkommen, prøver han at opmuntre dem, der »blev tilbage«. Måske får de endnu en chance. Hvem ved?:

Hold ud, I trofaste kære, som stolt og mandeligt stred.

Det galder jer og os alle:

Hvem veed! Hvem veed! Hvem veed! ${ }^{34}$

\section{De besindige}

De fleste digtere meldte sig som Hoffmann og Henriksen på Flensborg-folkenes side og krævede de højeste ideale fordringer opfyldt. H.P. Hanssens folkeretslige linje, at det, som var dansk, skulle til Danmark, og at det ville være uret mod tyskerne og samtidig en latent trussel mod grænsen, hvis man blot krævede ind og fik en stor tysk flertalsbefolkning i den sydlige del af Slesvig med over grænsen, fandt ikke megen genklang i kampens hede. Det kom først senere, da man kunne se, at han havde haft ret. Men en enkelt stemme var der dog. Det var sekretæren i Københavns Højskoleforening, Ernst Jørgensen Borup, som $\mathrm{i}$ et rimbrev hyldede H.P. Hanssen, fordi han havde stået fast på sin linje trods det stærke krav om at få mere med:

Mens folkene råbte: »Hold læng're mod syd, da først når vi alle $i$ havn «. Du hørte på brændingens buldrende lyd, at der var grunde og revler mod syd, og fremad du styred din stavn. 
$\mathrm{Nu}$ råber de højt om svig og bedrag, om svigten i farens stund, - endskønt det dog nu er en afgjort sag, at hvis før båden gik over stag, var skuden gået på grund.

Han mener hermed, at hvis man havde krævet hele Slesvig med til Danmark, eller i hvert fald en væsentlig sydligere grænselinje, kunne det have kuldsejlet hele Genforeningen. En afstemning i hele det historiske Sønderjylland til Dannevirke eller Ejderen ville have givet et stort tysk flertal. Selv ved en samlet afstemning i $1 . \operatorname{og} 2$.zone ville resultatet have været tvivlsomt. Tyske stemmer i Syd- og Mellemslesvig kunne have afgiort, at hele Nordslesvig var forblevet tysk. Det var der mange, som ikke kunne eller ville se, og som derfor bebrejdede H.P. Hanssen, at han holdt kursen. Nogle gik end ikke af vejen for - som von Holstein Rathlou - at kalde ham en forrædder eller endog »Hans Peter Tysker«. Men Borup er ikke i tvivl. Med en mand som H. P. Hanssen ved roret ville Danmark være vel faren, skriver han og lader sit rimbrev munde ud i den rene førerdyrkelse:

Og derfor hilser og hylder vi dig som fører, som første mand.

Vi hylder dit mod og din vilje sej, og havde vi altid en fører som dig, da stod det vel til $\mathrm{i}$ vort land. ${ }^{35}$

Af samme holdning er digteren, officeren og skolemanden Jakob Klinkbys digt "På samlingsdagen«, også trykt under titlen "Efter afstemningen i 1.zone«, der må være skrevet ganske kort efter den 10 . februar. Mens de fleste digte i glæde over afstemningsresultatet kun har øje for den danske sejr og udtrykker en ensidig nationalisme, glemmer de, at der ved afstemningen også var nogle, der tabte. I modsætning hertil opfordrer Klinkby til forsoning mellem landsdelens to nationaliteter. Han er glad for den danske sejr, men fremholder, at det netop er i sejrens stund, man skal vise storsind. Danskerne må ikke glemme »et gammelt bud«, som, hvis det bliver holdt, »gi'er styrke, glæde, sammenhold og tugt $\ll$ :

"I stort og småt opfør dig mod de andre, som du må ønske, det mod dig skal ske«. Ad sådan vej må folkets forbund vandre, om det skal mestre tidens gru og vé. 
Hvad om vi prøved dette bud at følge,

ej blot mod nord, men og mod dem i syd? ${ }^{36}$

Her er en klar modsætning til den nationalisme, som udelukker alle andre og som »i sig selv har nok«. Vi skal leve videre, siger Klinkby, både i Sønderjylland og ude i verden, og det kan vi kun, hvis vi behandler hinanden ordentligt. Vi skal ikke besvare den tyske undertrykkelse af de danske før Genforeningen med en tilsvarende undertrykkelse nu, da det er danskerne, der sidder på magten i landsdelen. Og på samme måde må Folkenes Forbund, der dannedes på Versailleskonferencen 1919, lære at vise mådehold.

En lignende holdning ligger bag de digte, som Limfjordsdigteren, redaktør Thøger Larsen skrev, dybt grebet af de historiske og nationale begivenheder:

Ræk os hånden, broder!

Søster, græd ej mer!

Se, vor gamle moder

gennem tårer ler!

Og Dannebrog vajer nu søndenfor å imod Danmark.

Nu kommer de hjem, som utrættelig så efter Danmark.

Velkommen - og tak, at I ej tabte modet!

Velkommen - med ar efter korset og blodet! Jert flag skal I bære med $æ$ re! $!^{33}$

Han er dybt grebet, men der er langt til sentimentalitet. Og der er ingen chauvinistiske undertoner af had og selvhævdelse i disse vers.

Forfatterinden Ingeborg Maria Sick, der var internationalt kendt især for en lang række "guvernanteromaner", mindedes i et langt digt, som blev fremsagt som prolog ved en fest i Odd Fellow Palæet i København den 27.maj 1920 , en vandretur over Dybbøl, mens det endnu var tysk, sandsynligvis før verdenskrigen. Alt virkede så dansk på hende, ja, landskabet og skanserne syntes at synge for hende på hendes modersmål:

Thi modersmålet er det hjerteslag, som holder et folk i live.

Og nu er sejren i hus. Folkeafstemningen viste, at troen kan løfte bjerge, landet er på vej mod Danmark: 
Nu jubler det danske fuglekor

på Dybbøls vårlige banker ...

$\mathrm{Nu}$ falder de knugende skranker! ${ }^{37}$

\section{Dybbølfesten 1920}

Lyrikeren Axel Juel, der var kontorchef i marineministeriet, var en slags officiel sanger ved nationale lejligheder, og 1919 skrev han en digtcyklus $»$ Sange om Dannebrog«. Den fremførtes som kantate med musik af Harding Sonne, da kongen fik overrakt et nyt rigsbanner den 15.juni 1919 på 700 års-dagen for slaget ved Lyndanisse, hvor Dannebrog som bekendt "faldt fra himlen ned«. Det mest kendte af digtene er »Der er ingenting, der maner ...«, der dog var skrevet allerede 1916, og som stadig er meget anvendt ved flaghejsning $i$ spejderlejre og lignende steder. Meget aktuelt sluttede han med en sang om "Sønderjylland og Dannebrog«, der har en næsten kælen tone i billedet af de elskende:

I blev fremmede folk i jert urgamle hjem, I har ventet befrielsens dag som den elskedes billed i løn taget frem, har I gemt på et dyrebart flag.

Det er uret, der mister sit knugende tag, det er Danmark, der ånder påny!

Når jert hjerte befris og vort elskede flag, er der smil gennem gråd - er der gry! ${ }^{38}$

Den 10.juli 1920 red kongen over den gamle grænse og ind i Sønderjylland på en hvid hest. Hestens farve var valgt for at fuldbyrde en gammel spådom, som sagde, at den danske konge en gang skulle holde sit indtog i den genvundne landsdel på denne måde:

Han red $i$ en bølgende menneskestrøm, han red $i$ en jublende skare for ene at fuldbyrde slægternes drøm og sagnenes magt at bevare.

Folket trængtes om kongen, »der var drot over hjerter, « som Juel skriver, og en lille pige klædt $i$ hvidt blev rakt op imod ham. Kongen tog hende op til sig 
(efter at have fået lov af moderen), gav hende et kindkys og red på den måde ind i Sønderjylland med den lille pige foran sig på hesten:

Og pigen hun åbned sin barnlige favn, som havde hun længe ham savnet;

hun kendte vel næppe sin konge af navn, men hjertelig glad hun omfavned:

Den mand, der bar fryden i Danmark. ${ }^{39}$

Det var måske digtene til flaget, der gjorde, at Axel Juel kom til at skrive den ene af de to nye sange, der blev sunget ved Dybbølfesten den 11.juli 1920. Den går på melodien til »Vort modersmål er dejligt«:

Fra hver sin side over å vi spejded, du og jeg; nu ser vi samme morgenskær, nu ser vi samme vej!

$\mathrm{Nu}$ skal vi sammen stride, og det gør stærk og glad, og før skal vore hjerter dø end atter skilles ad!

Han mindes derefter de faldne i Dybbølslaget, hvis grave nu ligger inden for Danmarks grænse. Det er frugten af deres offer, som nu kan høstes:

Nu hviler de i Danmarks jord, nu sover de i fred; det, de engang gav livet for, fik vi at glædes ved. ${ }^{40}$

Axel Juel skrev endnu et digt til festen. Det fremsagdes af en veteran fra krigen 1864, Hans Thomsen, da han overrakte kong Christian et gammelt Dannebrog, som familien Reimers i Sønderborg havde haft gemt siden 1864:

Vi har elsket det, mens vore hjerter led;

hjerter brast, men ikke deres kærlighed.

Den fik vore børn i arv, og med vort sprog har vi givet dem at elske Dannebrog.

Ved dets dug svor nye slægter faneed Tag vort gamle flag, og tag vor trofasthed! ${ }^{41}$

Dagen efter Dybbølfesten begyndte kongeparret en rundrejse i Sønderjylland, og ved Kruså mødte de en deputation af danske fra Flensborg. De var blevet "på den anden side grænsen / af retfærdighed «, d.v.s. i uretfærdigheden. De 
oplevede ikke retfærdigheden på samme måde som dem, der boede nord for den ny grænse og derfor blev genforenet med Danmark:
Men med et i sælsom tysthed
standser toget brat -
og det er, som mødes dagen
med den mørke nat.
Ingen hurra, ingen jubel, ingen glædes-dåd -
selve sorgen standser lykken
med sin bitre gråd.
Det var dem, som måtte blive
- skønt de taprest stred - på den anden side grænsen af retfærdighed.

Det var »dog den allerbedste hilsen, / Danmarks konge fik«, for det var den slags "stærke sind «, der "gav ham retten til at ride / i sit rige ind«, siger Juel. Og »denne stolte sorg« tog kongen så med »i sit hjerte inderst inde«, da han vendte tilbage $»$ til sin borg ${ }^{42}{ }^{42}$

Den anden officielle sang til Dybbølfesten var skrevet af digteren og forsikringsmanden, cand.jur. Niels Moller til melodien "Den signede dag med fryd vi ser«. Også denne sang holdt sig i mere end et halvt århundrede i Højskolesangbogen, selv om den er en ophobning af klichéer:
Den gryed omsider den favre dag,
vi havde i hu så længe,
og atter lyser det røde flag
på sønderjydernes vænge,
hvor atter i Danmarks frie mål
tør tale møer og drenge. ${ }^{43}$

Her er poetiske lån (for nu at sige det pænt) fra Ingemanns "Storken sidder på bondens tag«, hvori linjen »nu kommer den favre tid, vi vented så længe,« der også anvendtes på en af de kendteste afstemningsplakater, forekommer. Oehlenschlægers »Der er et yndigt land « med de »ædle kvinder, skønne møer / og mænd og raske svende«, måske endog »det røde flag«, som Niels Juel hejsede i Ewalds »Kong Christian«, spøger i baggrunden. Der er ikke meget originalt $\mathrm{i}$ dette vers. 
Valdemar Rørdam og Axel Juel var tilstede ved Dybbølfesten. Hvem af de øvrige digtere, der selv var med, ved jeg ikke, men mon dog ikke også Dumreicher og Kaj Hoffmann var der?

I hvert fald deltog Johannes Jørgensen, der i sommeren 1920 var i Danmark for første gang, efter at han syv år tidligere var emigreret til Italien, hvor han havde fundet blivende hjem i den hellige Frans' by Asissi, og hvor han havde vundet sig et internationalt navn som katolsk forfatter, bl.a. af helgenbiografier. Under dette hjemmeophold besøgte han også sin gamle skolekammerat fra Svendborg Latinskole, Peter Grau i Pøl på Als, som tog ham med til Genforeningsfesten, hvor Grau selv skulle tale.

Jørgensen har skildret den bevægede dag i essaysamlingen "Danimarca«, hvor han også i et stærkt følelsesladet brev til Grau advarer mod den tendens, han har sporet til at være sig selv nok. Til at mure sig inde i sit eget og lukke af for alt udefra. At være tilfreds med det danske og afvise alt tysk og fornægte den europæiske samhørighed, sådan som Kaj Hoffmann på skræmmende vis havde givet udtryk for. For den kosmopolitiske katolik var det farlig, ja vanvittig tale, idet han naturligvis klart så, hvad Danmark og dansk kultur havde modtaget fra resten af Europa, og at en indelukket selvtilstrækkelighed ville være det samme som åndeligt selvmord. ${ }^{44}$

I et stort digt (»Det genvundne land«) følger han denne tankegang op. Vi skal være glade og taknemlige for Genforeningen, men var den egen fortjeneste? Vi skal være klar over, hvem vi skylder den:

Det var ikke os selv, som med væbnet hånd førte brødrene hjem.

Og derefter viser han os, hvem vi kan takke for Genforeningen. Med storslået patos og nærmest som et litani lader han dem marchere frem for vore øjne, alle de soldater, som faldt på Europas slagmarker i 1. verdenskrig for at nedkæmpe tyskerne: belgiere, englændere, franskmænd og den italienske bersagliere, »som farvede dansk / Monte Grappas evige sne«. Et makabert billede, men umisforståeligt i sin symbolik.

Det var amerikanere, serbere, montenegrinere, mærkeligt nok omtaler han ikke russerne, de var der da også, søfolkene nævnes, og de utallige civile ofre, de voldtagne kvinder og forældreløse børn:

dem, der blev dræbt hin langfredag de var gået hen til Guds hus ved den niende time skælvede jorden, og kirken lå skudt $\mathrm{i}$ grus 
... alle enker og mødre, som græder

fra Bryssel og ned til Rom -

Det er dem, vi skal vise taknemlighed:

det er alle dem, som har kæmpet,

og alle dem, som har lidt, det er alle dem, som nu kommer og siger:

»Tag landet! Vi giver det frit! $\aleph^{45}$

Det er en hel befrielse at læse Johannes Jørgensens lidenskabelige forsvar for dem, der virkelig led og kæmpede, oven på de velhyttede danske digteres flommeord. Men heller ikke han er helt retfærdig. $\$ 6000$ unge sønners liv var dine løsepenge«, skrev Pontoppidan, selv om tallet som nævnt er overdrevet. Sønderjyderne betalte selv en blodig pris for retten til at stemme efter det tyske nederlag.

Men, og det er det paradoksale, havde den tyske hær (og dermed de sønderjyske soldater) vundet krigen, var der aldrig blevet en genforening. Sønderjyderne vandt, fordi de tabte. Fordi ententens hære slog aksemagterne (Tyskland og dets allierede), fik sønderjyderne mulighed for at stemme. Krigens nederlag blev fredens sejr.

Digteren og litteraturkritikeren Kaj Friis Moller, hvis bedstefar indtil 1864 havde været præst i Hanved syd for Bov (i 2. zone), mindedes dennes demonstration under tyskernes fremrykning mod nord i 1864 :

... og i kirkens tårn, på trods, ved midnatstid hejste de Danmarks flagdug, rød og hvid.

Bedstefaderen flyttede efter fordrivelsen "midlertidigt« til København. Hans embede var i Hanved, sagde han, og der skulle han tilbage. Derfor ville han hverken købe hus eller leje en permanent bolig, det ville være at opgive håbet, nærmest forræderi:

- Jeg hørte om Bedstefa'r, den fredens mand, der i sin tro på Gud og England lejede rolig ved hovedstaden blot en sommerbolig:

I syvogfyrre somre vented han ...

Men nu er dagen der! Hanved skal atter blive dansk, det skylder vi de trofaste døde, hvad så end de "visne, vise mænd«, politikere og diplomater, måtte sige og gøre: 
Fra Hanved kirke dages Danebroge, højt løfted af håbet i de dødes hær:

O hør, de døde kalder fjern og nær de døde, som får intet hvilested, før vi har regnet deres røster med! Vid, det er grufuldt i sin grav at bløde fri dem for det, hils fra de danske døde og sig de visne, vise mænd, at end for os er Hanved Danmark, simpelthen! ${ }^{46}$

\section{"Moderen«}

Det kongelige Teater bestilte et festspil hos digteren Helge Rode, som indleverede eventyrspillet »Moderen«, der udkom på Gyldendal i 1920 og havde premiere på scenen i januar året efter. Det er en underlig blanding af hverdagsrealisme, moralfilosofi og lyriske stemninger. Væsentligst i det er de smukke sange, hvoraf især én har vist sig levedygtig langt ud over stykket, som ellers er bedst tjent ved en nådig død i glemsel.

Det er den eneste af tidens sange, som har kunnet gøre "Det lyder som et eventyr « rangen stridig som sangen om Genforeningen, "Som en rejselysten flåde«, der er et af Helge Rodes fineste digte, både i form og indhold:

Hårdt går hav mod bro og stavn, møder Danmarks stille navn.

Hør, hvor blidt det klinger!

Hvor vi stod, og hvor vi gik, kom dit navn som sød musik, blødt på hvide vinger.

Han karakteriserer sproget, det danske sprog, som er anvendeligt under alle livets forhold, $\mathrm{i}$ otte lange, men dog mundrette ord:

Vinterklart og sonmmerbroget, morgenmuntert, skumringssvøbt, ligefremt og latterkroget, smilbestrålet, tåredøbt. 
Det er flot gjort!

Digtet indeholder en ukunstlet, uopstyltet glæde ved Danmark og det danske, som kun få har formået at give så smukt udtryk for:
Indånd Nordens frie luft, stilhed sød af blomsterduft, storm som søen salter, medens vi med trofast sind sætter al vor gerning ind, Danmark, på dit alter!

To vers, skrevet i samme versemål, fremtræder i skuespillet som et selvstændigt digt: »Søndret folk er vokset sammen«. Her finder vi de berømte linier:
Frem af vinter vælder vår, helet er vort gamle sår, bødet Danmarks flænge. Sorgomsuste Kongeå, atter skal din vove gå glad igennem enge,

der blev anvendt som indskift på genforeningsstenen i Rødding - og sikkert også andre steder. I dette digt findes også linjerne:

Uden tryk af fremmed åg klinger nu det rene sprog, som vor moder taler.

Eget brød til egen dug, Danmarks hvede, Danmarks rug Dybbøl Mølle maler. ${ }^{47}$

De findes også i "Som en rejselysten flåde« med en lidt anden formulering $i$ forste halvdel af verset: "Det er Danmarks frie sprog, / uden tryk af fremmed åg / frejdig Freja taler«. Rode har åbenbart ikke helt kunne blive enig med sig selv om, hvad der var bedst, og derfor har han valgt det kompromis at skrive to digte med de næsten identiske, men dog let afvigende formuleringer.

Digteren og dramatikeren Peder R. Moller skrev sangen »Hjem «, der blev sat i musik af Jacob Jørgensen, og som han dedikerede til fru Ellen Grau. På omslaget anføres, at sangen er blevet sunget af kgl. kammersanger Johannes Fønss. Møller tramper i de vante spor, og mor/barn-symbolikken er fremherskende: 
Nu er dagen der, da vi omsider atter kan vende hjem til mor. ${ }^{48}$

Den dengang meget læste romanforfatter A.J. Geilager brugte Kongeåen som symbol i et genforeningsdigt. Åen »nynned' ... tungt sin klagesang«, mens »gråden blinked i dens bølger«, thi »mor og barn« var »af voldsmænd skilte«, og

Sønderjyllands sønner blødte

fjernt på fremmed jord

i den store krig. Men det er altsammen forbi, »solen (har) sejret«, og »dagen (er) lys og blid «:

Nu skal mor og datter mødes, synke favn i favn

(...)

$\mathrm{Nu}$ forbinder åens vande, hjerteligt og mildt, dobbelt fast de tvende, som af strømmen før var skilt. ${ }^{49}$

\section{Fra krig til genforening}

Den sønderjyske digter Hansigne Lorenzen fra Ballum, der i tysk tid - og til dels også senere - skrev under navnet Sven Tange, hørte til dem, der var aktive fra første færd.

Allerede 1.december 1918 - mindre end 14 dage efter Aabenraa-mødet sendte hun en artikel til »Flensborg Avis«, hvori hun agiterede for en sydligere grænselinie end den, H.P. Hanssen og hans rådgiver, magister H.V.Clausen, gik ind for. Heri var også to digte, et større om verdenskrigens tab og et mindre på kun to vers, hvor hun allerede havde taget glæderne på forskud, uden - naturligvis - at ane, hvilke kampe og skuffelser der lå forude:

$\mathrm{Nu}$ fik vi grænsen flyttet, og helt blev Danmarks skjold.

Og flaget fik vi plantet

på Thyras gamle vold.

Nu kan vi bænke glæden, hvor før der tungt blev grædt;

thi nu er sejren vundet

for sandhed og for ret. ${ }^{50}$ 
Hansigne Lorenzen (18701952) var larerdatter og senere larerkone i Ballum. Da hendes mand kravedes forflyttet på grund af familiens danskhed, kobte agteparret en gård. Hun skrev en rakke romaner og mange digte under pseudonymet Sven Tange, og selv om hun hverken er nogen sarlig dyb eller original digter, fik hun stor betydning som en klar og konsekvent dansk stemme $i$ Sonderjylland under projservaldet. Foto: Dansk Centralbibliotek for Sydslesvig.

I 1919 udsendte hun det lange fortællende digt, bl.a. om guldhornene, "Arveguld «, der var skrevet fem år tidligere, men som måtte vente med at udkomme, til der atter var fred. Heri findes et indledningsdigt, som må være skrevet efter fredsslutningen, og som hun havde fået ingen ringere end Carl Nielsen til at skrive melodi til. Den skal spilles »fast og værdigt«, står der over nodebladet. Hun anvender her en versform og et billedsprog, inspireret af Oehlenschlægers "Guldhornene«, idet hun også indfører genforeningstidens symboler, moderen og morgengryet (det sidste ikke mindre end tre gange i de to korte vers!):

Mørket viger,

dagen stiger,

klokker kimer højt mod sky,

helhest snubler,

folket jubler

mod det unge morgengry.
Slukt er sorgen, glædens morgen

rinder op, trods suk og savn, mens i varme

moderarme sødt vi nynner Danmarks navn. ${ }^{51}$ 
Overgangstiden mellem dansk og tysk styre betød bl.a. en besættelse af franske og engelske tropper, der af de danske sønderjyder opfattedes som et sikkert tegn på løsrivelsen fra Tyskland, og derfor hilstes med glæde. Hansigne Lorenzen tolkede de danske følelser ved disse troppers ankomst. Hun takkede dem for deres indsats i krigen og bød dem velkommen:

Thi mens tricoloren vajer over vore sønners grave, har vi nynnet Marseillaisen her i Danmarks gamle have.

og

For fred og folkefrihed du stred med tappert sind, da stred du dig i alle, alle danske hjerter ind, du brittens brave søn!

Hansigne Lorenzen og hendes kreds levede som de fleste dansksindede sønderjyder intenst med i alt, hvad der skete $\mathrm{i}$ denne tid, og hun registrerede de vigtigste begivenheder i vers, bl.a. kongens ridt over grænsen på den hvide hest. Og da kongen på sin rundrejse efter festlighederne på Dybbøl kom til Tønder, bød hun ham velkommen på Torvet med et drapa i vikingeforsiring (hil, ætling, snække):

Hil dig, Kong Christian,

Dankongers ætling! -

Snækken dig vugged

ind mod vor kyst.

Dagen efter besøgte kongeparret hendes og hendes mands hjem i Ballum. Her bød hun dronning Alexandrine velkommen med et digt, der symbolsk overrakte dronningen en buket blomster. Den stilfærdige, inderlige tone passer bedre til hendes gemyt end den højstemte svulstighed, som hun ellers alt for let falder for. Her er hun ren og ægte. Her taler kvinde til kvinde:

Vi ejer ej skove

til læog til lyst, men bølgen sig boltrer

frit mod vor kyst -

og hist hvor i engene

åen sig snor

et blånende væld

af kærminder gror. 
Du skal eje dem alle, vor dronning så god ...52

Ganske vist, siger hun, "fløjet er den tyske ørn / fra Slesvigs nordre vange«, og wveget er den lede trold / til jætters skumle rige«, for så vidt angår landet nord for den nye grænse. Men syd for den bor der stadig danske, som også (efter hendes mening) har krav på at »komme hjem«. De skal dog ikke fortvivle,

thi aldrig spurgtes før i nord, at dansken sveg sin næste.

Hendes vikingesymbolik stikker næsen frem overalt, også når hun nævner Sydslesvigs danske mindesteder som »Ansgars gamle kirke« i Hedeby,

og ledet ved vort danske hus

er Thyras Dannevirke.

Sydslesvigerne skal ikke fortvivle. Vi kommer og befrier dem; hun fantaserer om, at de nordiske lande vil hjælpe os, og når sejren er i hus, genopbygger vi Dannevirke som Nordens grænsefæstning mod syd og bringer ledet i lave:

Men trøst dig kun, du danske mand

i landet længst mod sønder; snart kører frem det jyske spand

og Nordens gæve bønder, og volden vil vi bygge op om Danmarks gamle have, og ej vi spare sjæl og krop, før ledet er i lave. ${ }^{53}$

Det var måske denne krigeriske ønsketænkning, der fik hende til at byde de danske soldater velkommen til Nordslesvig på denne måde:

Vær velkommen danske drenge

nu da somrens sange synges, vi har ventet $-\mathrm{a}-$ så længe. ${ }^{54}$

Der er en helt anden tone i Gram-præsten Johan Zerlangs digte. Han mistede en søn under 1. verdenskrig, og det satte dybe spor. Han skrev adskillige dybt 


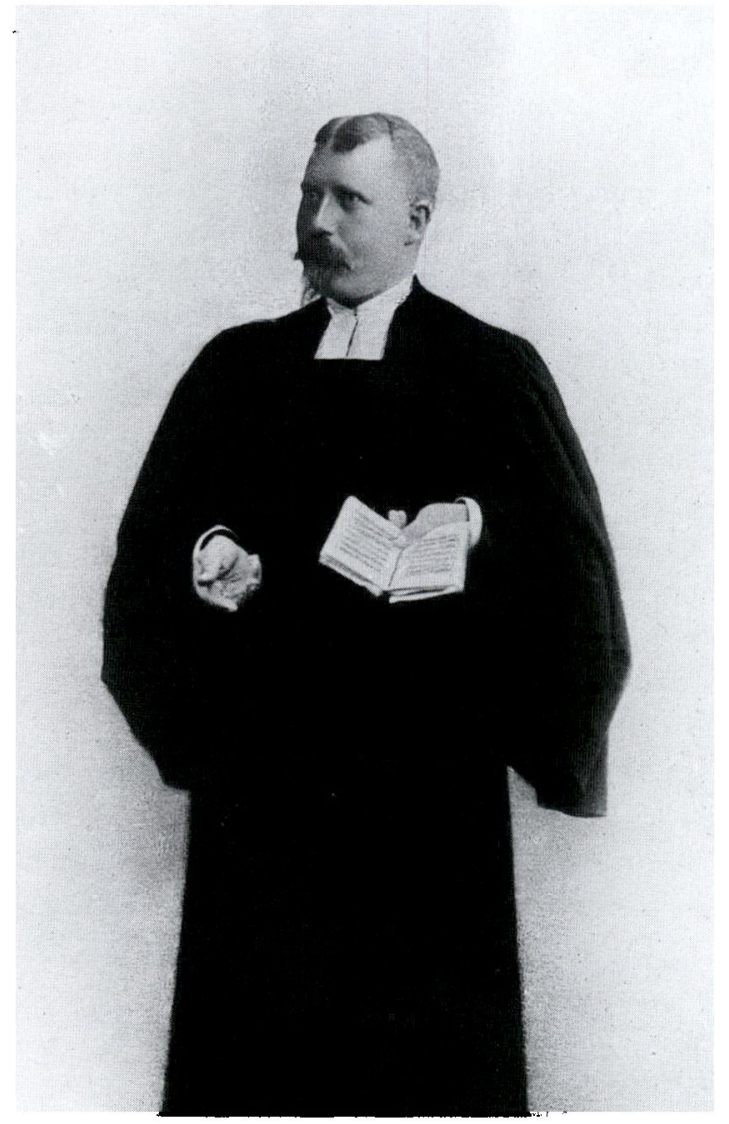

Johan Zerlang (1864-1924) var prost i Gram fra 1899 til sin dod. Han skrev adskillige fine digte, praget af en smidig versifikatorisk evne og en inderlig kristentro, selv om man nappe kan kalde ham for en dyb eller sarlig original lyriker. Han mistede en sen under verdenskrigen, og dette tab pragede derefter hans digtning pd̊ afgørende måde. Zerlang er her ifort den tyske landskirkes prastedragt. Men han var en af de mest dansksindede proster $i$ Sonderjylland og blev genvalgt med stort flertal i 1920. Foto: Institut for sonderjysk lokalhistorie.

følte mindedigte, hvor han grublede over sit ufattelige og uerstattelige tab. Hvad kunne dog meningen være? Hvorfor havde Gud taget hans dreng på denne meningsløse måde?

Tabet lå lige under overfladen, og det mærkes i det meste af, hvad han skrev. Men Genforeningen gav ham en slags trøst. Drengen var ikke død helt forgæves:

Thi takker jeg Gud vor fader histoppe i Himmerig. Forgæves er ikke død min dreng, som faldt i den store krig. 
Hans stilfærdige, inderlige vers tolker på en meget fin måde de mange tanker og følelser, der rørte sig i ham i den tid. Hans »sorgbehandling« havde sikkert også værdi for mange andre, der havde mistet sønner og andre nære slægtninge i krigen.

Genforeningen er Guds gave til det danske folk, som derfor bør takke ham:

\author{
Vi rejser korsets banner \\ på Sønderjyllands jord \\ med tak til ham, som danner \\ en verden ved sit ord.
}

Han mindes sin far, som var med i Treårskrigen 1848-50, og som altid havde indprentet ham kristendom og danskhed. Forældrene havde en drøm om, at grænsen igen ville blive rykket mod syd:

Den hjalp dem til at holde ud med håb i sjæl og sind og stole på den stærke Gud, som skifter sol og vind.

Den drøm hjælper også ham:

Jeg skimter bag islagt rude den soldag, vi håber på.

Og nu er dagen der:

Vi samles med vort folk i nord

i frihed og i glæde,

og atter kan vor danske jord

i rødt og hvidt sig klæde. ${ }^{55}$

Også pastor Anders Malling i Brøns havde haft en far, der var med i Treårskrigen, og den gamle mands beretninger og fromme kristendom satte sit præg på drengen. Hans poesi er mest af religiøs art, men digtkredsen "Danmarks kirke«, der er en poetisk genfortælling af kirkehistorien, slutter med et vers om Genforeningen. Han tænker på tabene i verdenskrigen, og bruger i øvrigt Pontoppidans billede af »en røvet datter«, der vender »hjem til moders hus «, hvor hendes sår skal læges ved moderens kærlige pleje. Datteren kan nu frit på modersmålet takke Gud for sin redning: 


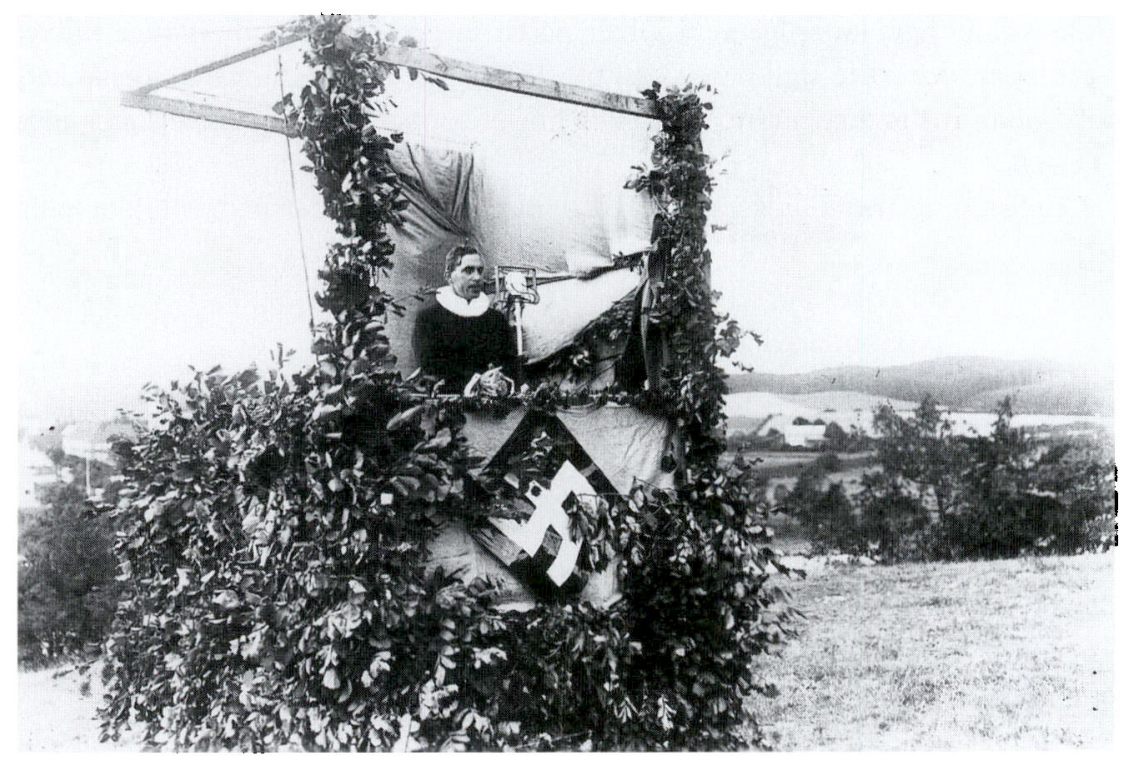

Anders Malling (1896-1981) var prast i Brons i 42 ar. Han skrev $i$ 1920'erne en rakke digtsamlinger, isar med religiost indhold, hvor han ofte viste en smidig sproglig evne, men indholdsmassigt nappe nåede under overfladen. Som starkt konservativ og nasten religiost national meldte han sig $i$ begyndelsen af 1930 'erne ind i nazistpartiet, men forlod det igen for 1936 at danne sit eget semifascistiske parti Dansk Folkefallesskab. Det bestod dog kun i få år og opnåede ikke nogen politisk indflydelse. På sine aldre dage var han mest kendt som en fortjenstfuld salmehistoriker. Billedet er taget, da Malling pradikede på nazistpartiets landsmode i Aabenraa 1934. Foto: Institut for Sonderjysk Lokalhistorie.

\author{
Sidst vi fik den folkeglæde, \\ at den fangne datter fri \\ kan med moders tunge kvæde \\ takkesang med vemod $\mathrm{i}$. \\ Give Gud for Jesu blod, \\ at den frelste datter god \\ under moders hænder milde \\ læges må ved livets kilde. ${ }^{56}$
}

\title{
»... stod Tønder i rødt og hvidt«
}

Genforeningens fuldbyrdelse - Danmarks overtagelse af landsdelen - har ikke inspireret så mange digtere. Men én har dog givet et klart, stærkt og skarpt øjebliksbillede af nationalitetsskiftet. Det er Johannes Buchholtz, der ellers er mest kendt for sine romaner, men ligesom Pontoppidan fik han i forbindelse 
Johannes Buchholtz (18821940) var ansat som trafikassistent i DSB og boede i mange år $i$ Struer som byens forende kulturpersonlighed, museumsgrundlogger m.v. Han er mest kendt for sine mange romaner. bl.a. "Egholms gud" fra 1915 og var o. 1930 Danmarks måske mest laste forfatter. 1920 blev han af Statsbanerne sammen med andre jernbanefolk sendt til Sonderjylland for at stả for skiftet fra tysk til dansk jernbanedrift. Herom skrev han digtet „På Tondern stationw. Foto: Struer Museum.

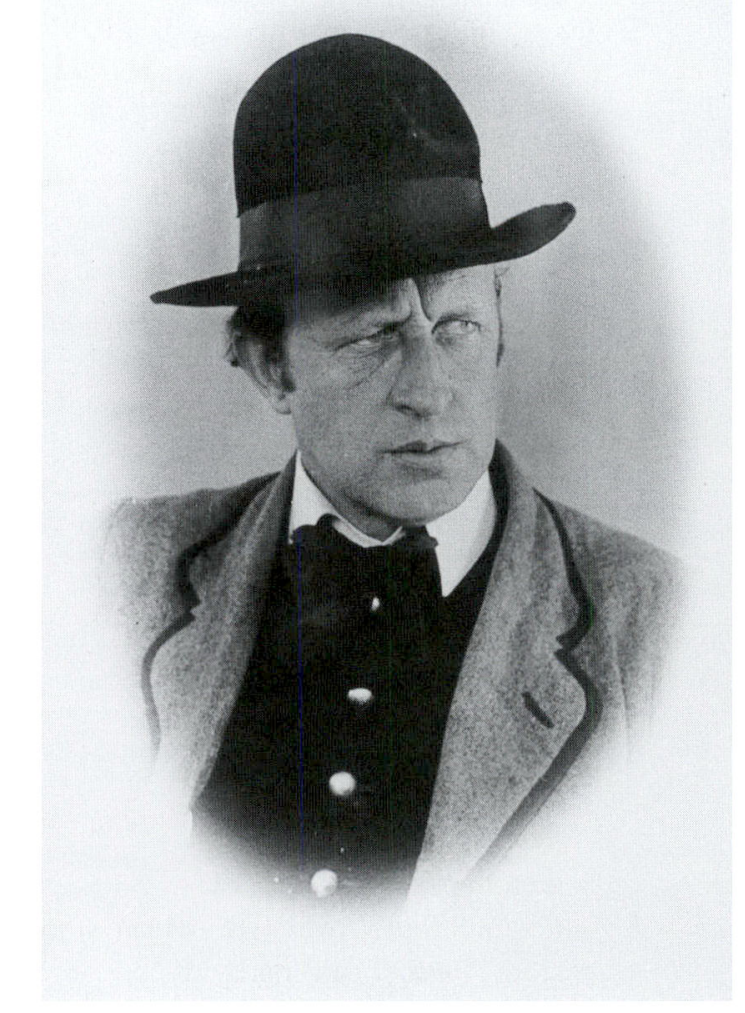

med Genforeningen en oplevelse, som for en enkelt gangs skyld fik ham til at skrive vers. Og hvilke vers! Simple og enkle, dybtfølte og i rent hverdagssprog uden påklistrede metaforer og bombastiske armbevægelser.

I 1920 blev Buchholtz, der var ansat som trafikassistent under statsbanerne, sendt til Tønder med de første DSB-funktionærer for at stå for skiftet fra tysk til dansk jernbanedrift. I en artikel i »Sønderjysk Månedsskrift« har han fortalt om det:

"Jeg havde ikke direkte med overtagelsen at gøre, sørgede bare for ikke at være i vejen, gik op og ned ad perronen, grebet af det mærkelige, som skete omkring mig: et stykke Danmarkshistorie, i ganske lille format måske, men til gengæld meget ægte og ganske uden pomp og pragt. En tysk station blev dansk. « ${ }^{57}$

I digtet »På Tondern Station« skildres nationalskiftet så enkelt: 
I den slørede juninat var luften fredfyldt og lun, over Tonderns 1ste perron fløj flagermus bløde som dun.

Fra den stille, grønne marsk kom langeligt brøl af en ko - men på Tonderns 1ste perron brødes den natlige ro.

Danske jernbanemænd med funklende huer på sned satte beslutsomt en stige til og tog nogle skilte ned.

Ikke en sabel rasled gennem den natlige fred: man rejste bare en stige og tog nogle skilte ned.

Verden har mange sprog, men dansk det er nu mit. Forunderligt - over 1ste perron stod Tonder i rødt og hvidt.

Sagte som plov vender muld eller bøg strækker roden i jord, strakte mit land sin rod, så langt som de danske bor. ${ }^{58}$

Det sidste vers virker påklistret, som en unødvendig morale, en over-tydeliggørelse, som slet ikke behøves. Alt er jo sagt i det foregående vers (»Stod Tønder i rødt og hvidt $)$.

\section{Gennem tidens sigte}

Det var meget højtstemte følelser, der kom til udtryk i genforeningstidens digte, ofte i et særdeles bombastisk sprogleje, som i dag skurrer i ørerne, når man ved, hvad disse ord mindre end et par årtier senere kunne bruges til, i nogle 
tilfælde af de samme mænd. Nok ikke helt tilfældigt meldte tre af de digtere med det højeste toneleje - Rørdam, Malling og von Holstein Rathlou - sig i 30 'erne og 40 'erne under de nazistiske faner ${ }^{59}$. Men de fleste af digterne holdt dog stien ren.

Det er også karakteristisk, at næsten alle de digte, der blev skrevet »til lejligheden «, nu er glemt. Og de 4-5 stykker, der endnu synges eller kendes, hører blandt de mere stilfærdige. Den store patos har ingen klangbund i dag, den lyder hul og uægte i det moderne øre og kalder mere på det ironiske smil end på den ægte følelse.

Henrik Pontoppidans "Det lyder som et eventyr« og Helge Rodes "Som en rejselysten flåde« er de eneste af genforeningstidens mange sange, der synges $\mathrm{i}$ dag. Og sammen med Buchholtz’ »På Tondern station «, Johannes Jørgensens "Det genvundne land« og måske Kaj Friis Møllers »Hanved« er det stort set, hvad tidens store sigte har ladet blive tilbage af de flere hundrede digte, som begivenhederne og de stærke følelser i 1918-20 frembragte.

Og det er måske i grunden slet ikke så ringe endda.

\section{NOTER OG HENVISNINGER}

Alle citater er gengivet med moderne retskrivning.

LB=Det sønderjyske Landsbibliotek. SM=Skærbækegnens Museum.

ED-J=Materiale samlet af højskolelærer Elsemarie Dam-Jensen, Løgumkloster. De øvrige tilhører forfatteren.

1. Poul Kürstein (red.): Flensborg Avis 1869-1969. 1969.

2. A.Gammelgaard: Seks tusind unge sønners liv - var dine løsepenge. Sønderjysk Månedsskrift, 1970,2. + Jørgen Kühl og Jens Ødegaard: Dansksindede sønderjyske krigsdeltagere og faldne i Første Verdenskrig. Sønderjyske Årbøger, 1990.

3. Vilh. la Cour (red): Sangen om Sønderjylland. Forord af Vilhelm Andersen. Aschehoug, 1919.

4. samme.

5. Valdemar Rørdam: Hjemme i Sønderjylland. Gyldendal, 1919.

6. Valdemar Rørdam: Regnbuen. Aschehoug, 1919.

7. samme.

8. Vilh. la Cour (red): Sangen om Sønderjylland. Aschehoug, 1919.

9. Valdemar Rørdam: Taktløs tale. Litterært Forlag, 1924.

10. Valdemar Rørdam: Sangen om Danmark. 2. udg., Gyldendal, 1941.

11. Vilh.la Cour (red): Sangen om Sønderjylland. Aschehoug, 1919.

12. samme.

13. Carl Dumreicher: Til landsmænd sønden å. Kantate ved Sønderjyllands genforening med Danmark år 1920. Privattryk, uden år.

14. Carl Dumreicher: Genforeningen 1920. Gads Forlag, 1920.

15. H.Lausten-Thomsen: Genforeningsdagene. Tønder Amts Centraltrykkeri, 1943.

16. Gudrun Jarnøe: Til Sønderjylland. Afskrift. ED-J.

17. Ingeborg Simesen (red): Danske Fædrelandssange. Dansklærerforeningen og Gyldendal, 1920. LB.

18. samme.

19. Anders Diemer: Nu kommer de tilbage. Edvard Eller (red): Sønderjysk Centralforenings festskrift. Fergos Forlag, 1920. SM. 
20. Niels Jeppesen: Slesvigs sønner. Gyldendal, 1919.

21. Georg Brandes: Sønderjylland under prejsisk tryk. Gyldendal, 1919.

22. Ingeborg Simesen (red): Danske Fædrelandssange. Danbsklærerforeningen og Gyldendal, 1920. LB.

23. Holger Drachmann: Derovre fra grænsen. Genforeningsudgave med forord af Poul Drachmann. Gyldendal, 1919.

24. Johs. V. Jensen: Årstiderne. Gyldendal, 1923.

25. Ernst Kaper: Den største stund vor slægt har oplevet. Dybbølfesten 11. juli 1920. Uden udgiver og årstal.

26. Otto Didrik Schack: Grænsesind. Gyldendal, 1970.

27. Jeppe Aakjær: Goddaw ijen. Opr. i »Pressens Magasin«, februar 1920. Her efter Højskolesangbogen, 1959.

28. Kaj Hoffmann: Sværdtid er endt. Pios forlag, 1920. LB.

29. Poul Kürstein (red): Nørre og Sønder Gøs herred (Poul Kürstein: Folkeafstemningen 1920). Forlaget Skandia, 1969.

30. Kaj Hoffmann: Sværdtid er endt. Pios forlag, 1920. LB.

31. Viggo J. von Holstein Rathlou: Det forjættede land. Slesvigske digte. Flensborg og Århus, 1925. Dansk Centralbibliotek, Flensborg.

32. Viggo J. von Holstein Rathlou og Jørgen Wind: Slesvig, vort elskede omstridte land. Haderslev 1925.

33. Thøger Larsen: I Danmarks navn. Gyldendal, 1920.

34. Hans Henriksen: Folkets mand. Aschehoug, 1920.

35. Ernst Jørgensen Borup: En hilsen til H. P. Hanssen fra 1920. Heimdal 10/2-1930. SM.

36. Jakob Klinkby: På samlingsdagen. Trykt i Oplevelser, en lille, men virkelig livs-roman. Konrad Jørgensens Bogtrykkeri, Kolding, 1927. LB.

37. Ingeborg Maria Sick: Til de sønderjyske kvinder. Dybbølposten, 15/7-1930. SM.

38. Axel Juel: Sange om Dannebrog. Pios forlag, 1919.

39. Axel Juel: Kongeventyret. Gyldendal, 1942.

40. Sange ved Genforeningsfesten på Dybbøl 1920.

41. samme.

42. Axel Juel: Kongeeventyret. Gyldendal, 1942.

43. Ved hjemkomsten. Danmarks Rigsdag til de danske sønderjyder. Dybbøl 1920.

44. Johannes Jørgensen: Danimarca. Gyldendal, 1921.

45. Johannes Jørgensen: Der er en brønd som rinder. Gyldendal, 1920.

46. Kaj Friis Møller: Indskrifter, 1920. Her efter Carl Bergstrøm-Nielsen: Dansk lyrik fra Johannes V. Jensen til Harald Bergstedt. Gyldendal, 1963.

47. Helge Rode: Moderen. Gyldendal, 1920.

48. Peder R. Møller: Hjem. Brdr. Jørgensen, Sønderborg. u.å. ED-J.

49. Til festlighederne i anledning af Genforeningen 1920. J. Otsens bogtrykkeri, Sønderborg, 1920. ED-J.

50. Sven Tange (Hansigne Lorenzen): Skal Dannebrog plantes på Thyras gamle vold? "Flensborg Avis«, 23/12-1918, her efter »Endnu er det tid«. Hagerups forlag, 1919.

51. Hansigne Lorenzen: Arveguld. Det Schønbergske forlag, 1919.

52. Hansigne Lorenzen: Tider og steder. Hagerups forlag, 1927.

53. Thyra Petersen (red): Ved afstemning i Sønderjylland 1920. Grenå, 1920. SM.

54. Hansigne Lorenzen: Tider og steder. Hagerups forlag, 1927.

55. Johan Zerlang: Tanker og toner. Axel Wedels Boghandel, Gramby, 1926.

56. Anders Malling: Danmarks kirke. De unges forlag, 1926.

57. Johannes Buchholtz: Mulden, hvoraf et digt spirede. Sønderjysk Månedsskrift, sept. 1939.

58. Johannes Buchholtz: På Tondern station. Oprindelig i »Ravne og runer«, 1921. Her efter Sønderjysk Månedsskrift, sept. 1939.

59. Ole Ravn: Dansk nationalsocialistisk litteratur 1930-45. Berlingske Forlag, 1979. 